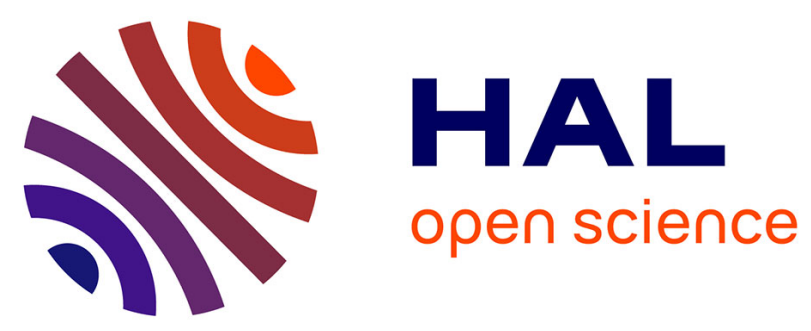

\title{
Influence of serum albumin and the flavonol quercetin on the peroxidase activity of metmyoglobin
}

\author{
Bénédicte Lorrain, Claire Dufour, Olivier O. Dangles
}

\section{To cite this version:}

Bénédicte Lorrain, Claire Dufour, Olivier O. Dangles. Influence of serum albumin and the flavonol quercetin on the peroxidase activity of metmyoglobin. Free Radical Biology and Medicine, 2010, 48 (9), pp.1162-1172. 10.1016/j.freeradbiomed.2010.01.037 . hal-02662225

\section{HAL Id: hal-02662225 \\ https://hal.inrae.fr/hal-02662225}

Submitted on 30 May 2020

HAL is a multi-disciplinary open access archive for the deposit and dissemination of scientific research documents, whether they are published or not. The documents may come from teaching and research institutions in France or abroad, or from public or private research centers.
L'archive ouverte pluridisciplinaire HAL, est destinée au dépôt et à la diffusion de documents scientifiques de niveau recherche, publiés ou non, émanant des établissements d'enseignement et de recherche français ou étrangers, des laboratoires publics ou privés. 


\title{
Influence of serum albumin and the flavonol quercetin on the peroxidase activity of metmyoglobin
}

\author{
Bénédicte Lorrain, Claire Dufour, Olivier Dangles*
}

INRA, University of Avignon, UMR408, F-84000 Avignon, France

\footnotetext{
* Corresponding author. Fax: +33 490144441 .
}

E-mail address: Olivier.Dangles@univ-avignon.fr (O. Dangles) 
Version définitive du manuscrit publié dans / Final version of the manuscript published in : Free Radical Biology and Medicine, 2010, Article in press, DOI:10.1016/j.freeradbiomed.2010.01.037

Lorrain et al. Free Radical Biol. Med. 2010

\begin{abstract}
Metmyoglobin $\left(\mathrm{MbFe}^{\mathrm{III}}\right)$, a major form of dietary iron, is an efficient inducer of lipid and protein oxidation. Indeed, $\mathrm{MbFe}^{\mathrm{III}}$ is able to cleave hydrogen peroxide and lipid hydroperoxides with subsequent formation of ferrylmyoglobin $\left(\mathrm{MbFe}^{\mathrm{IV}}=\mathrm{O}\right)$ and lipid oxyl and peroxyl radicals. In the first part of this work, the mechanism of the reaction between $\mathrm{MbFe}^{\mathrm{III}}$ and $\mathrm{H}_{2} \mathrm{O}_{2}$ is revisited with an emphasis on the influence of bovine serum albumin (BSA). BSA does not affect the rate of $\mathrm{MbFe}^{\mathrm{IV}}=\mathrm{O}$ formation but inhibits the formation of the redox-inactive green pigment (heme-protein cross-link species). Although tightly bound to $\mathrm{BSA}$, the flavonol quercetin is still able to reduce $\mathrm{MbFe}^{\mathrm{IV}}=\mathrm{O}$ as a likely result of long-range electron transfers within a protein-protein complex. In a second part, BSA is shown to strongly slow down the metmyoglobin-catalyzed consumption of linoleic acid hydroperoxides with formation of ketones as the main products. In the process, only low concentrations of ferrylmyoglobin are slowly accumulated. A catalytic mechanism is proposed that involves a one-electron oxidized metmyoglobin species distinct from ferrylmyoglobin.
\end{abstract}

Keywords: Metmyoglobin; Hydrogen peroxide; Lipid hydroperoxide; Quercetin; Serum albumin; Free radicals. 
Version définitive du manuscrit publié dans / Final version of the manuscript published in : Free Radical Biology and Medicine, 2010, Article in press, DOI:10.1016/j.freeradbiomed.2010.01.037

Lorrain et al. Free Radical Biol. Med. 2010

\section{Introduction}

The reaction of myoglobin $\left(\mathrm{MbFe}^{\mathrm{II}}\right)$ and metmyoglobin $\left(\mathrm{MbFe}^{\mathrm{III}}\right)$ with hydrogen peroxide has been thoroughly studied for its implication in the oxidative deterioration of meat [1] and, more generally, its relevance in the development of oxidative stress via lipid and protein modifications [2-4]. Since myoglobin and metmyoglobin are the main forms of dietary iron, these heme proteins could also trigger lipid peroxidation in the gastric compartment following a meal including red meat (the main source of heme iron) and polyunsaturated lipids [5]. In such circumstances, traces of lipid hydroperoxides could replace $\mathrm{H}_{2} \mathrm{O}_{2}$ for the activation of heme iron to hypervalent forms involved in the initiation of the peroxidation process [6]. Protection against this diet-related oxidative stress could have nutritional significance from at least two viewpoints: the preservation of dietary lipids essential to cell functioning and the protection against the toxicity of potentially harmful lipid oxidation products (hydroperoxides, aldehydes, epoxides) and the highly reactive radical intermediates (e.g., lipid oxyl and peroxyl radicals) involved in their formation [7]. Interestingly, given their low ability to cross the intestinal barrier (absorption), common dietary plant antioxidants such as polyphenols could have their antioxidant action essentially restricted to the gastro-intestinal (GI) tract [8]. However, the peroxidase activity of $\mathrm{MbFe}^{\mathrm{III}}$ is clearly dependent on several factors such as $\mathrm{pH}$, the hydroperoxides under consideration and the presence of other proteins, which could interact with $\mathrm{MbFe}^{\mathrm{III}}$ and/or the antioxidant [2]. As part of our ongoing program to investigate the heme-induced peroxidation of polyunsaturated dietary lipids and its inhibition by antioxidants $[9,10]$, we now wish to report on the influence of bovine serum albumin (BSA) and the flavonol quercetin, one of the most common flavonoid aglycones in plants and in human diet, on the peroxidase activity of metmyoglobin. This study provides a basis for the rationalization of the heme-induced peroxidation of protein-stabilized lipid emulsions in food and in the GI tract [11]. It can also be noted that serum albumin is the carrier of the fraction of dietary polyphenols that enters the blood circulation (as conjugates) following intestinal absorption $[12,13]$. 


\section{Materials and methods}

\section{Chemicals}

Horse heart myoglobin ( $\mathrm{MbFe}^{\mathrm{II}}$, MW ca. $17600 \mathrm{~g} \mathrm{~mol}^{-1}$ ), hydrogen peroxide (30\% in water), quercetin and bovine serum albumin (fraction V A-9647, MW ca. $66500 \mathrm{~g} \mathrm{~mol}^{-1}$ ) were purchased from Sigma-Aldrich. Upon dissolution in the phosphate buffer, $\mathrm{MbFe}^{\mathrm{II}}$ is quicky converted into $\mathrm{MbFe}^{\mathrm{III}}$ by autoxidation. The phosphate buffer (5 mM, pH 5.8) was prepared with Millipore Q-Plus water and passed through a column of Chelex-100 chelating resin (BioRad) to remove contaminating metal ion traces. The preparation and purification of the linoleic acid hydroperoxides were carried out as described in the literature [14]. Based on the contamination of the samples by the corresponding (redox inactive) alcohols and ketones, a purity of $c a .80 \%$ can be assumed.

\section{Absorption and emission spectra}

Absorption spectra were recorded on a Hewlett-Packard 8453 diode-array spectrometer equipped with a quartz cell (optical pathlength: $1 \mathrm{~cm}$ ). The temperature in the cell was kept at $37^{\circ} \mathrm{C}$ by means of a water-thermostated bath. Magnetic stirring in the cell at a constant rate (1000 rpm) was ensured by a Variomag stirrer (Telemodul 20C). Steady-state fluorescence spectra were recorded at $37^{\circ} \mathrm{C}$ on a thermostated Safas Xenius spectrofluorometer. The excitation and emission slit widths were set at $10 \mathrm{~nm}$.

\section{Formation of ferrylmyoglobin and its reduction by quercetin}

A $60 \mu \mathrm{M}$ solution of metmyoglobin $\left(\mathrm{MbFe}^{\mathrm{III}}\right.$, concentration determined spectrophotometrically using $\varepsilon=7700 \mathrm{M}^{-1} \mathrm{~cm}^{-1}$ at $525 \mathrm{~nm}$ ) in the $\mathrm{pH} 5.8$ phosphate buffer was thermostated at $37^{\circ} \mathrm{C}$ in the spectrophotometer cell in the presence or absence of BSA (3 equiv.). After a few minutes, $30 \mu \mathrm{L}$ of a concentrated aqueous solution of $\mathrm{H}_{2} \mathrm{O}_{2}(4 \mathrm{mM}$, concentration determined spectrophotometrically using $\varepsilon=39.4 \mathrm{M}^{-1} \mathrm{~cm}^{-1}$ at $240 \mathrm{~nm}$ ) were added (final $\mathrm{H}_{2} \mathrm{O}_{2}$ concentration in the cell $=60 \mu \mathrm{M}$ ). The conversion of $\mathrm{MbFe}^{\mathrm{III}}$ into ferrylmyoglobin $\left(\mathrm{MbFe}^{\mathrm{IV}}=0\right)$ and its subsequent auto-reduction was monitored by the increase 
Version définitive du manuscrit publié dans / Final version of the manuscript published in : Free Radical Biology and Medicine, 2010, Article in press, DOI:10.1016/j.freeradbiomed.2010.01.037

Lorrain et al. Free Radical Biol. Med. 2010

of the absorbance at $590 \mathrm{~nm}$ over a few minutes. The procedure was repeated with $\mathrm{H}_{2} \mathrm{O}_{2}$ in excess (10 equiv.) for the determination of the molar absorption coefficient of $\mathrm{MbFe}^{\mathrm{IV}}=\mathrm{O}$.

In the experiments with 1 equiv. $\mathrm{H}_{2} \mathrm{O}_{2}, 20 \mu \mathrm{L}$ of a concentrated solution of quercetin in $\mathrm{MeOH}$ (final quercetin concentrations in the cell: 15,30 and $60 \mu \mathrm{M}$ ) were added once the formation of $\mathrm{MbFe}^{\mathrm{IV}}=\mathrm{O}$ was completed. Then, the reduction of $\mathrm{MbFe}^{\mathrm{IV}}=\mathrm{O}$ was monitored at $590 \mathrm{~nm}$ (time interval between 2 consecutive spectra $=0.5 \mathrm{~s}$ ).

In the absence of quercetin, the set of equations used in the curve fitting procedures is as follows ( $A_{0}$ : initial absorbance, $\mathrm{C}$ : total heme iron concentration):

$A(590 \mathrm{~nm})=A_{0}[\mathrm{MbFe}] / \mathrm{C}+\varepsilon_{1}[\mathrm{MbFe}=\mathrm{O}]+\varepsilon_{2}[\mathrm{oxMbFe}]+\varepsilon_{3}[\mathrm{GMbFe}]$

$-\frac{d}{d t}[\mathrm{MbFe}]=-\frac{d}{d t}\left[\mathrm{H}_{2} \mathrm{O}_{2}\right]=\left(k_{1}+k_{3}\right)[\mathrm{MbFe}]\left[\mathrm{H}_{2} \mathrm{O}_{2}\right]$

$\frac{d}{d t}[\mathrm{MbFe}=\mathrm{O}]=k_{1}[\mathrm{MbFe}]\left[\mathrm{H}_{2} \mathrm{O}_{2}\right]-k_{2}[\mathrm{MbFe}=\mathrm{O}]$

$\frac{d}{d t}[\mathrm{oxMbFe}]=k_{2}[\mathrm{MbFe}=\mathrm{O}]$

$\frac{d}{d t}[\mathrm{GMbFe}]=k_{3}[\mathrm{MbFe}]\left[\mathrm{H}_{2} \mathrm{O}_{2}\right]$

In the presence of BSA, the formation of GMbFe was neglected $\left(k_{3}=0, \varepsilon_{3}=0\right)$.

In the presence of quercetin $(\mathrm{Q})$, one simply has:

$-\frac{d}{d t}[\mathrm{MbFe}=\mathrm{O}]=k_{\mathrm{r}}[\mathrm{MbFe}=\mathrm{O}][\mathrm{Q}]-k_{2}[\mathrm{MbFe}=\mathrm{O}]$

$-\frac{d}{d t}[\mathrm{Q}]=k_{\mathrm{r}}[\mathrm{MbFe}=\mathrm{O}][\mathrm{Q}]$

Activation of $\mathrm{MbFe}^{I I I}$ by the linoleic acid hydroperoxides

Kinetic analysis by $U V$-vis spectroscopy in the visible range. In a first series of experiments, $30 \mu \mathrm{L}$ of a $10.8 \mathrm{mM}$ solution of $\mathrm{LOOH}$ in 2-propanol $(i-\mathrm{PrOH})$ were added to 2 $\mathrm{mL}$ of a MbFe ${ }^{\mathrm{III}}$ and BSA solution (respective concentrations $=60$ and $180 \mu \mathrm{M}$ ) in the $\mathrm{pH} 5.8$ phosphate buffer at $37^{\circ} \mathrm{C}$. In a second series of experiments, to facilitate the solubilization of $\mathrm{LOOH}$, an equimolar solution of BSA and $\mathrm{LOOH}(150 \mu \mathrm{M}, i$-PrOH content $<1.5 \%)$ was prepared, stirred for a few minutes and transferred to the spectrometer cell $(2 \mathrm{~mL})$. Then, 0.1 $\mathrm{mL}$ of a $1.25 \mathrm{mM} \mathrm{MbFe}{ }^{\mathrm{III}}$ solution in the phosphate buffer was added. Final concentrations in the cell were $180 \mu \mathrm{M}$ for BSA, $144 \mu \mathrm{M}$ for $\mathrm{LOOH}$ and $60 \mu \mathrm{M}$ for $\mathrm{MbFe}^{\mathrm{III}}$. After $\mathrm{A}(590 \mathrm{~nm})$ 
had reached a constant value, $20 \mu \mathrm{L}$ of a concentrated solution of quercetin in $\mathrm{MeOH}$ were added (final quercetin concentrations $=30-125 \mu \mathrm{M}$ ). The same procedure was repeated with 8 equiv. LOOH. Experiments without BSA were also carried out by using a minimal LOOH concentration ( 0.8 equiv.).

In the experiments with BSA and 9- or 13-LOOH in excess (8 equiv.), the slow development of ferryl absorption in the visible range was analyzed according to the following kinetic model:

$$
\begin{aligned}
& A(590 \mathrm{~nm})=A_{0}[\mathrm{MbFe}] / \mathrm{C}+\varepsilon_{1}[\mathrm{MbFe}=\mathrm{O}]+\varepsilon_{\mathrm{a}}\left[\mathrm{MbFe}-1 \mathrm{e}^{-}\right] \\
& -\frac{d}{d t}[\mathrm{MbFe}]=\left(k_{1}+k_{\mathrm{a}}\right)[\mathrm{MbFe}][\mathrm{LOOH}]-k_{\mathrm{b}}\left[\mathrm{MbFe}-1 \mathrm{e}^{-}\right][\mathrm{LOOH}] \\
& \frac{d}{d t}\left[\mathrm{MbFe}-1 \mathrm{e}^{-}\right]=k_{\mathrm{a}}[\mathrm{MbFe}][\mathrm{LOOH}]-k_{\mathrm{b}}\left[\mathrm{MbFe}-1 \mathrm{e}^{-}\right][\mathrm{LOOH}] \\
& \frac{d}{d t}[\mathrm{MbFe}=\mathrm{O}]=k_{1}[\mathrm{MbFe}][\mathrm{LOOH}] \\
& -\frac{d}{d t}[\mathrm{LOOH}]=\left(k_{1}+k_{\mathrm{a}}\right)[\mathrm{MbFe}][\mathrm{LOOH}]+k_{\mathrm{b}}\left[\mathrm{MbFe}-1 \mathrm{e}^{-}\right][\mathrm{LOOH}] \\
& \frac{d}{d t}[\mathrm{~L}=\mathrm{O}]=\left(k_{1}+k_{\mathrm{a}}\right)[\mathrm{MbFe}][\mathrm{LOOH}]
\end{aligned}
$$

Kinetic analysis by spectroscopic monitoring of the Soret band: The same procedure was applied with the following final concentrations: 0 or $9 \mu \mathrm{M}$ for BSA, $9.6 \mu \mathrm{M}$ for LOOH (added last) and $3 \mu \mathrm{M}$ for $\mathrm{MbFe}^{\mathrm{III}}$. The experiment was repeated with $\mathrm{H}_{2} \mathrm{O}_{2}(3 \mu \mathrm{M})$ for comparison.

Kinetic analysis of $L O O H$ consumption by HPLC: The same procedure was applied with the following final concentrations: 0 or $18 \mu \mathrm{M}$ for BSA, $24 \mu \mathrm{M}$ for LOOH, $6 \mu \mathrm{M}$ for $\mathrm{MbFe}^{\mathrm{III}}$ (added last). Every $30 \mathrm{~s}$, a volume of $0.2 \mathrm{~mL}$ was taken up and acidified with $10 \mu \mathrm{L}$ of $0.12 \mathrm{M} \mathrm{HCl}$. After addition of $0.2 \mathrm{~mL}$ of tetrahydrofurane/ $\mathrm{CH}_{3} \mathrm{CN}(2: 3)$, the mixture was centrifuged for $3 \mathrm{~min}$ at $10^{4} \mathrm{rpm}$ and the upper layer frozen until HPLC analysis according to already described conditions [14].

Quenching of the fluorescence of the quercetin-BSA by metmyoglobin

The fluorescence intensity of the quercetin-BSA complex (noted $I_{F}$ ) at $535 \mathrm{~nm}$ is gradually quenched by increasing concentrations of the metmyoglobin ligand (noted $L$ ). The 
experimental procedure is as follows: to $2 \mathrm{~mL}$ of an equimolar solution of BSA and quercetin (concentration $=40 \mu \mathrm{M}$ ) in the $\mathrm{pH} 5.8$ phosphate buffer placed in the spectrofluorometer cell were added small samples $(10 \mu \mathrm{L})$ of a $450 \mu \mathrm{M}$ metmyoglobin solution in the same buffer. Assuming a 1:1 binding between the two proteins, an optimized value for the binding constant (K) was estimated by fitting the $I_{F} v s . L_{t}$ curve against Eqs. (14)-(16) where $L_{t}$ is the total $\mathrm{MbFe}^{\mathrm{III}}$ concentration, $C$ the total BSA concentration and $f_{P}$ the molar fluorescence intensity of the quercetin-BSA complex (the fluorescence of free quercetin is negligible).

$$
\begin{aligned}
& I_{F}=f_{P}[P] \exp \left[-\left(\varepsilon_{L}^{e x}+\varepsilon_{L}^{e m}\right) l L_{t}\right] \\
& L_{t}=[L](1+K[P]) \\
& C=[P](1+K[L])
\end{aligned}
$$

Since $\mathrm{MbFe}^{\mathrm{III}}$ substantially absorbs light at the excitation and emission wavelengths (450 and $535 \mathrm{~nm}$, respectively), an inner filter correction is necessary. In Eq. 1, the $\varepsilon_{\mathrm{L}}$ parameters stand for the molar absorption coefficients of $\mathrm{MbFe}^{\mathrm{III}}$ at the excitation and emission wavelengths. Their values are determined independently by UV-visible spectroscopy from a Beer's plot $\left(\varepsilon_{\mathrm{L}}\right.$ $=8300$ and $6500 \mathrm{M}^{-1} \mathrm{~cm}^{-1}$ at 450 and $535 \mathrm{~nm}$, respectively). Finally, $l$ is the mean distance travelled by the excitation light at the site of emission light detection. For the spectrometer used in this work, $l$ is estimated to be $0.65 \mathrm{~cm}$.

\section{Data analysis}

The curve-fitting and derivation procedures of the absorbance $v s$. time plots were carried out on a PC using the Scientist program (MicroMath, Salt Lake City, USA). Beer's law and sets of differential kinetic equations with initial conditions on concentrations were given as input data. Curve-fittings were achieved through least square regression and yielded optimized values for the parameters (kinetic rate constants, molar absorption coefficients). 


\section{Results and discussion}

All experiments have been conducted in mildly acidic conditions ( $\mathrm{pH}$ 5.8) corresponding to the $\mathrm{pH}$ of meat and of the gastric compartment experiencing the buffering effect of the dietary bolus in the early phase of digestion [15].

\section{Activation of metmyoglobin by hydrogen peroxide}

The complete set of the reactions taking place between metmyoglobin and $\mathrm{H}_{2} \mathrm{O}_{2}$ is presented on Scheme 1. Hydrogen peroxide triggers a two-electron oxidation on $\mathrm{MbFe}^{\mathrm{III}}$ with the simultaneous formation of an iron-oxo center $\left(\mathrm{Fe}^{\mathrm{IV}}=\mathrm{O}\right)$ and a protein radical located on Tyr-103 or Trp-14. This activated form of metmyoglobin is called perferrylmyoglobin $\left(\mathrm{Mb}^{\bullet} \mathrm{Fe}^{\mathrm{IV}}=\mathrm{O}\right)$. In the absence of external sources of electrons, perferrylmyoglobin rapidly evolves toward the more stable ferrylmyoglobin $\left(\mathrm{MbFe}^{\mathrm{IV}}=\mathrm{O}\right)$ upon a poorly understood process called auto-reduction. During auto-reduction, $\mathrm{Mb}$ is the most likely source of electrons and actually dityrosine residues can be evidenced along the globin chain [16]. Alternatively, in slightly acidic solutions, a second pathway can occur that probably originates from a protonated form of $\mathrm{Mb}^{\bullet} \mathrm{Fe}^{\mathrm{IV}}=\mathrm{O}\left(\mathrm{Mb}^{\bullet} \mathrm{Fe}^{+}-\mathrm{OH}\right)$ and consists in the formation of $\mathrm{a}$ covalent bond between the porphyrin nucleus and Tyr-103. In this process, a green pigment $\left(\mathrm{GMbFe}^{\mathrm{III}}\right)$ is formed $[17,18]$. In the presence of external sources of electrons (antioxidants, polyunsaturated lipids, proteins), both $\mathrm{Mb}^{\bullet} \mathrm{Fe}^{\mathrm{IV}}=\mathrm{O}$ and $\mathrm{MbFe}^{\mathrm{IV}}=\mathrm{O}$ can be reduced. In particular, $\mathrm{MbFe}^{\mathrm{IV}}=\mathrm{O}$ is a potent initiator of lipid peroxidation $[6,19]$ while $\mathrm{Mb}^{\bullet} \mathrm{Fe}^{\mathrm{IV}}=\mathrm{O}$ efficiently abstract electrons from proteins to produce long-lived protein radicals [16,20]. In its more oxidizing protonated form $\left(\mathrm{pK}_{\mathrm{a}} \approx 5\right)$, ferrylmyoglobin is as efficient as $\mathrm{Mb}^{\bullet} \mathrm{Fe}^{\mathrm{IV}}=\mathrm{O}$ at producing protein radicals from BSA as judged from the amount of diTyr produced [20]. Finally, $\mathrm{MbFe}^{\mathrm{IV}}=\mathrm{O}$ itself can evolve by a slow auto-reduction process. Its reduction by various antioxidants including several polyphenols has been investigated [9,21-23].

When a mildly acidic solution of $\mathrm{MbFe}^{\mathrm{III}}$ (visible absorption maximum at $505 \mathrm{~nm}+$ minor band with a maximum at $635 \mathrm{~nm}$ ) is treated by $\mathrm{H}_{2} \mathrm{O}_{2}$, the formation of $\mathrm{MbFe}^{\mathrm{IV}}=\mathrm{O}$ can be evidenced by the increase in visible absorption at 550 and $590 \mathrm{~nm}$ (Fig. 1A). When the experiments are repeated in the presence of BSA (3 equiv.), significant changes can be 
observed: although BSA does not alter the visible spectrum of $\mathrm{MbFe}^{\mathrm{III}}$, its influence on the activation process is manifested by the band at $550 \mathrm{~nm}$ being now slightly more intense that the band at $590 \mathrm{~nm}$ while the reverse is obvious in the absence of BSA (Fig. 1B). In fact, the final spectrum is very similar to the one of $\mathrm{MbFe}^{\mathrm{IV}}=\mathrm{O}$ at neutral $\mathrm{pH}$ [21-23] i.e. in conditions where the formation of the green pigment is negligible. Thus, we propose that BSA essentially quenches the formation of $\mathrm{GMbFe}^{\mathrm{III}}$, which in the absence of BSA is manifested by the development of a strong absorption at $590 \mathrm{~nm}$ in agreement with the literature [6].

Because $\mathrm{MbFe}^{\mathrm{IV}}=\mathrm{O}$ is contaminated by the inert $\mathrm{GMbFe}^{\mathrm{III}}$ in the absence of BSA, the subsequent step of $\mathrm{MbFe}^{\mathrm{IV}}=\mathrm{O}$ auto-reduction or reduction by quercetin is manifested by relatively small spectral changes since the potential for regeneration of $\mathrm{MbFe}^{\mathrm{III}}$ from $\mathrm{MbFe}^{\mathrm{IV}}=\mathrm{O}$ is low (Fig. 2). By contrast, BSA ensures a large conversion of $\mathrm{MbFe}^{\mathrm{III}}$ into $\mathrm{MbFe}^{\mathrm{IV}}=\mathrm{O}$ and a subsequent large regeneration of $\mathrm{MbFe}^{\mathrm{III}}$ either by auto-reduction or, much more rapidly, by electron transfer from quercetin (Fig. 2). Since BSA radicals are known to be produced from the reaction of $\mathrm{BSA}$ with $\mathrm{Mb}^{\bullet} \mathrm{Fe}^{\mathrm{IV}}=\mathrm{O}[16,20,24]$, the transient intermediate in $\mathrm{MbFe}^{\mathrm{III}}$ activation, part of quercetin can also be consumed by electron transfer to the BSA radicals themselves. In addition, the slow decay of $\mathrm{MbFe}^{\mathrm{IV}}=\mathrm{O}$ in the presence of $\mathrm{BSA}$, which is slightly faster than in the absence of BSA, could reflect not only the auto-reduction process but also the reduction of the iron-oxo center by BSA.

For a quantitative kinetic analysis, a simplified set of reactions between metmyoglobin and $\mathrm{H}_{2} \mathrm{O}_{2}$ was considered (Scheme 2). The calculations (see Experimental Section for details) were first run in the simpler situation of $\mathrm{MbFe}^{\mathrm{III}}$ reacting with $\mathrm{H}_{2} \mathrm{O}_{2}$ in the presence of BSA (GMbFe ${ }^{\mathrm{III}}$ neglected). After $\mathrm{H}_{2} \mathrm{O}_{2}$ addition (1 equiv.), the $\mathrm{A}(590)$-time curve was recorded over $30 \mathrm{~min}$ (Fig. 2A) for the monitoring of $\mathrm{MbFe}^{\mathrm{IV}}=\mathrm{O}$ formation (fast step, second-order rate constant $k_{1}$ ) and subsequent decay (slow step, first-order rate constant $k_{2}$ ) into an oxidized $\mathrm{Fe}^{\mathrm{III}}$ species noted oxMbFe ${ }^{\mathrm{III}}$. When the reaction is repeated with an excess of $\mathrm{H}_{2} \mathrm{O}_{2}(10$ equiv.), the decay of $\mathrm{MbFe}^{\mathrm{IV}}=\mathrm{O}$ is no longer detectable (Fig. 2B) and the plateau value of $\mathrm{A}(590 \mathrm{~nm})$ can now be used to estimate the molar absorption coefficient of $\mathrm{MbFe}^{\mathrm{IV}}=\mathrm{O}: \varepsilon_{1}=$ $9450( \pm 110) \mathrm{M}^{-1} \mathrm{~cm}^{-1}(n=2)$. On the other hand, the curve-fitting of the $\mathrm{A}(590 \mathrm{~nm}) v s$. time curves collected with 1 equiv. of $\mathrm{H}_{2} \mathrm{O}_{2}$ allows to estimate $k_{2}$ as well as the molar absorption coefficient of oxMbFe ${ }^{\mathrm{III}}: k_{2}=18.8( \pm 0.7) \times 10^{-4} \mathrm{~s}^{-1}, \varepsilon_{2}=4820( \pm 40) \mathrm{M}^{-1} \mathrm{~cm}^{-1}(n=2)$. Then, sets of experiments on shorter periods of time (2-3 min) were run (1 equiv. of $\left.\mathrm{H}_{2} \mathrm{O}_{2}\right)$ to estimate $k_{1}\left(k_{2}\right.$ and $\varepsilon_{2}$ set constant at their values previously determined $): k_{1}=640( \pm 110) \mathrm{M}^{-1}$ $\mathrm{s}^{-1}(n=6)$. At the end of each run, quercetin $\left(\mathrm{MbFe}^{\mathrm{III}} /\right.$ quercetin molar ratio $=1,2$ and 4$)$ was 
added to monitor the kinetics of its oxidation by $\mathrm{MbFe}^{\mathrm{IV}}=\mathrm{O}$ (Fig. 2C). From the concentrations of the different heme species determined prior to quercetin addition and taking into account $\mathrm{MbFe}^{\mathrm{IV}}=\mathrm{O}$ auto-reduction ( $k_{2}$ value previously determined), the decay of $\mathrm{A}(590$ $\mathrm{nm}$ ) could be analyzed to extract the second-order rate constant $k_{\mathrm{r}}$ for the reduction of $\mathrm{MbFe}^{\mathrm{IV}}=\mathrm{O}$ by quercetin: $k_{\mathrm{r}}=680( \pm 120) \mathrm{M}^{-1} \mathrm{~s}^{-1}(n=6)$.

To address the more complicated situation of $\mathrm{MbFe}^{\mathrm{III}}$ activation and subsequent reduction in the absence of $\mathrm{BSA}$, the rate constant $k_{1}$ for the formation of $\mathrm{MbFe}^{\mathrm{IV}}=\mathrm{O}$ and its molar absorption coefficient $\varepsilon_{1}$ were set at mean values estimated in the presence of BSA. Then, the A(590)-time curves recorded over 30 min with 1 equiv. of $\mathrm{H}_{2} \mathrm{O}_{2}$ (Fig. 2A) were analyzed according to a kinetic model assuming the competitive formation of $\mathrm{MbFe}^{\mathrm{IV}}=\mathrm{O}$ and $\mathrm{GMbFe}^{\mathrm{III}}$ (rate constant $k_{3}$, molar absorption coefficient $\varepsilon_{3}$ ) from $\mathrm{MbFe}^{\mathrm{III}}$ and the subsequent auto-reduction of $\mathrm{MbFe}^{\mathrm{IV}}=\mathrm{O}$ into $\mathrm{oxMbFe} \mathrm{III}^{\mathrm{III}}$. We thus obtained estimates for the autoreduction rate constant of $\mathrm{MbFe}^{\mathrm{IV}}=\mathrm{O}$ in the absence of $\mathrm{BSA}$ and the molar absorption coefficients of oxMbFe ${ }^{\mathrm{III}}$ and GMbFe ${ }^{\mathrm{III}}: k_{2}=30.1( \pm 1.8) \times 10^{-4} \mathrm{~s}^{-1}, \varepsilon_{2}=4580( \pm 200) \mathrm{M}^{-1} \mathrm{~cm}^{-1}$ (in good agreement with the value in the presence of BSA), $\varepsilon_{3}=12230( \pm 1150) \mathrm{M}^{-1} \mathrm{~cm}^{-1}(n=$ 2). As previously (in the presence of BSA), sets of experiments on shorter periods of time (2$3 \mathrm{~min}$ ) were finally run ( 1 equiv. of $\left.\mathrm{H}_{2} \mathrm{O}_{2}\right)$ to obtain a refined value for $k_{3}\left(k_{1}, k_{2}, \varepsilon_{1}, \varepsilon_{2}\right.$ and $\varepsilon_{3}$ set constant at their values previously determined), the $\mathrm{MbFe}^{\mathrm{IV}}=\mathrm{O}$ concentration at the time of quercetin addition and the value of the rate constant $k_{\mathrm{r}}$ of its oxidation by $\mathrm{MbFe}^{\mathrm{IV}}=\mathrm{O}: k_{3}=270$ $( \pm 110) \mathrm{M}^{-1} \mathrm{~s}^{-1}(n=6), k_{\mathrm{r}}=73( \pm 15) \times 10^{2} \mathrm{M}^{-1} \mathrm{~s}^{-1}(n=4)$.

Remarkably, BSA-bound quercetin remains able to reduce $\mathrm{MbFe}^{\mathrm{IV}}=\mathrm{O}$ although the corresponding rate constant is one order of magnitude smaller than in the absence of BSA. This is consistent with the propagation of radicals from $\mathrm{Mb}^{\bullet} \mathrm{Fe}^{\mathrm{IV}}=\mathrm{O}$ to $\mathrm{BSA}[16,20,24]$ and with our recent work that suggests the possibility of efficient long-range electron transfers connecting the periphery of serum albumin (which provides primary sites for oxidative attacks) and the quercetin binding site in sub-domain IIA [25]. It is also noteworthy that some reductants such as ascorbate and Trolox are able to reduce ferrylmyoglobin by two distinct mechanisms: a weak binding to the heme pocket with a subsequent fast reduction of the ferryl center and a stronger binding to another site followed by a relatively slow long-range electron transfer involving a critical Tyr residue [26].

The main results of the kinetic analysis are summarized in Table 1 . In the literature [27], the rate constant for the formation of $\mathrm{MbFe}^{\mathrm{IV}}=\mathrm{O}$ has been shown to be independent of 
$\mathrm{pH}$ in the range $5-7$. From the apparent first-order rate constant reported $\left(35 \times 10^{-4} \mathrm{~s}^{-1}\right.$ for initial $\mathrm{MbFe}^{\mathrm{III}}$ and $\mathrm{H}_{2} \mathrm{O}_{2}$ concentrations of $10 \mu \mathrm{M}$ ), a $k_{1}$ value of $350 \mathrm{M}^{-1} \mathrm{~s}^{-1}$ can be calculated at $25^{\circ} \mathrm{C}$, which is consistent with our value of $640 \mathrm{M}^{-1} \mathrm{~s}^{-1}$ at $37^{\circ} \mathrm{C}$. Unlike $k_{1}$, the rate constant of ferryl auto-reduction $\left(k_{2}\right)$ is strongly dependent on $\mathrm{pH}$ in the range 5-7 and sharply increases when the $\mathrm{pH}$ is lowered as a result of the formation of a protonated ferryl species. From the same article [27], the value estimated at $\mathrm{pH} 5.8$ and $25^{\circ} \mathrm{C}$ is $c a .5 \times 10^{-4} \mathrm{~s}^{-1}$, which is 6 times lower than the value estimated in our work. From the mean values of the rate constants, the concentrations of the different heme species following the addition of hydrogen peroxide to a mildly acidic solution of metmyoglobin can be plotted as a function of time in the presence or absence of serum albumin (Fig. 3). In the absence of BSA, it can be seen that the percentage of heme-protein cross-linked species $\left(\mathrm{GMbFe}^{\mathrm{III}}\right)$ amounts to slightly less than $30 \%$ of the total heme concentration at $\mathrm{pH} 5.8$ and $37^{\circ} \mathrm{C}$. A previous work using reverse-phase HPLC for the titration of the different heme species in solution concluded that this percentage is about $15 \%$ at room temperature [17].

In addition, an investigation by fluorescence spectroscopy suggests that metmyoglobin is able to bind to the quercetin-BSA complex $\left(K \approx 10^{5} \mathrm{M}^{-1}\right.$ based on our work [13]). Indeed, whereas we were unable to gain evidence of a direct interaction between metmyoglobin and quercetin (no significant quenching of the $\mathrm{MbFe}^{\mathrm{III}}$ intrinsic fluorescence pertaining to its $\operatorname{Trp}$ residues), a strong quenching of the fluorescence of the quercetin-BSA complex (excitation of bound quercetin at $450 \mathrm{~nm}$, emission collected at $535 \mathrm{~nm}$ ) was observed by increasing metmyoglobin concentrations (Fig. 4). A mathematical treatment of the quenching curve (see Experimental Section) provided the corresponding binding constant: $K=24.7( \pm 1.1) \times 10^{3} \mathrm{M}^{-1}$ $\left(\mathrm{pH} 5.8,37^{\circ} \mathrm{C}\right)(n=2)$. Hence, we propose that the reduction of ferrylmyoglobin by BSAbound quercetin takes place within a complex in which both proteins are associated.

In summary, BSA does not alter the activation of metmyoglobin into ferrylmyoglobin upon oxidation by $\mathrm{H}_{2} \mathrm{O}_{2}$ (nor the rate of ferrylmyoglobin auto-reduction) but quenches the covalent coupling between the heme cofactor of protonated $\mathrm{Mb}^{\bullet} \mathrm{Fe}^{\mathrm{IV}}=\mathrm{O}$ and the globin chain, possibly by direct reduction of the protein radical. In addition, BSA-bound quercetin is still able to reduce $\mathrm{MbFe}^{\mathrm{IV}}=\mathrm{O}$ (although less rapidly than in the absence of BSA). Consistently, quercetin efficiently inhibits lipid peroxidation in BSA-stabilized emulsions [11]. 
Activation of metmyoglobin by linoleic acid hydroperoxides

Even in the absence of hydrogen peroxide, $\mathrm{MbFe}^{\mathrm{III}}$ is a potent initiator of lipid peroxidation $[2,6,9,10]$. By analogy with investigations dealing with organic hydroperoxides, this process likely reflects the ability of metmyoglobin to cleave traces of lipid hydroperoxides $(\mathrm{LOOH})$ with concomitant formation of highly oxidizing species such as $\mathrm{MbFe}^{\mathrm{IV}}=\mathrm{O}$ and $\mathrm{LO}^{\bullet}$ (homolytic cleavage) and $/$ or $\mathrm{Mb}^{\bullet+} \mathrm{Fe}^{\mathrm{IV}}=\mathrm{O}$ (heterolytic cleavage with simultaneous formation of $\mathrm{LOH}$ ) [28]. However, during the metmyoglobin-induced peroxidation of linoleic acid, no significant formation of $\mathrm{MbFe}^{\mathrm{IV}}=\mathrm{O}$ can be evidenced. On the other hand, a concomitant decay of the Soret absorption band is observed that suggests a degradation of the porphyrin nucleus $[9,10]$. Hence, the true initiating species is not precisely characterized. A partially oxidized form of $\mathrm{MbFe}^{\mathrm{IV}}=\mathrm{O}$ can be assumed.

In this work, the reaction is investigated in details by using purified linoleic acid hydroperoxides (LOOH, mixture of 9-(10E,12Z)-LOOH, 9-(10E,12E)-LOOH, 13-(9Z,11E)$\mathrm{LOOH}$ and 13-(9E,11E)-LOOH) contaminated by minor amounts of the corresponding alcohols $(\mathrm{LOH})$ and ketones $(\mathrm{L}=\mathrm{O})$ [14]. The HPLC analysis of $\mathrm{LOOH}$ consumption confirms that the reaction is fast in the absence of BSA and follows an apparent first-order kinetics with $k_{\mathrm{obs}}=155( \pm 6) \times 10^{-3} \mathrm{~s}^{-1}$ (Fig. 5). The ketones come up as the major products of hydroperoxide consumption (apparent first-order rate constant for $\mathrm{L}=\mathrm{O}$ formation $=105( \pm$ 19) $\times 10^{-3} \mathrm{~s}^{-1}$ ) whereas the concentration of the corresponding alcohols ( $\mathrm{LOH}$ ) remains low and quasi-constant (data not shown). Thus, during the reaction, the $\mathrm{L}=\mathrm{O} / \mathrm{LOH}$ molar ratio increases from 0.7 to 3.3. The amount of lipid oxidation products distinct from $\mathrm{L}=\mathrm{O}$ and $\mathrm{LOH}$ (e.g., epoxyalcohols, cleavage products) is ca. 30\%. By contrast, 13-(9Z,11E)-LOH makes a major contribution to the products formed in the reaction of metmyoglobin with $13-(9 Z, 11 E)$ $\mathrm{LOOH}$ at $\mathrm{pH} 7.4$ and $25^{\circ} \mathrm{C}$ [29]. The bimolecular rate constant $k$ for the reaction between $\mathrm{LOOH}$ and $\mathrm{MbFe}^{\mathrm{III}}$ can be roughly evaluated from $k_{\mathrm{obs}}=k \mathrm{C}_{0}\left(\mathrm{C}_{0}\right.$ : initial metmyoglobin concentration $=6.2 \mu \mathrm{M})$. One obtains: $k \approx 25 \times 10^{3} \mathrm{M}^{-1} \mathrm{~s}^{-1}$. Given the obvious lack of sensitivity due to fast LOOH consumption (Fig. 5), this value can be regarded as a lower limit of the true $k$ value. In the literature [27], the pseudo-first order rate constant for $\mathrm{LOOH}$ consumption following addition of $\mathrm{MbFe}^{\mathrm{III}}$ was estimated from the decay of the absorbance at $234 \mathrm{~nm}$, which is characteristic of conjugated dienes. From the $k_{\mathrm{obs}}$ value at $\mathrm{pH} 6\left(\mathrm{ca} .0 .1 \mathrm{~s}^{-1}\right.$, initial $\mathrm{MbFe}^{\mathrm{III}}$ concentration $=10 \mu \mathrm{M}$ ), one obtains: $k=10^{4} \mathrm{M}^{-1} \mathrm{~s}^{-1}$ at $25^{\circ} \mathrm{C}$, which is consistent with our estimation at $37^{\circ} \mathrm{C}$. It is also noteworthy that a sharp increase in $k_{\mathrm{obs}}$ was 
observed when the $\mathrm{pH}$ was lowered from 6.5 to 5 [27]. This acceleration was ascribed to the formation of a protonated ferryl species with a radical character permitting its reaction with a second $\mathrm{LOOH}$ equivalent to form a lipid peroxyl radical $\mathrm{LOO}^{\bullet}$.

Although much slower, the consumption of BSA-bound LOOH gives similar results (Fig. 5): the ketones are the main products (final $\mathrm{L}=\mathrm{O} / \mathrm{LOH}$ molar ratio $=4.1,20 \%$ of other lipid oxidation products). The apparent rate constants for $\mathrm{LOOH}$ consumption and $\mathrm{L}=\mathrm{O}$ formation are $11.5( \pm 3.0) \times 10^{-3} \mathrm{~s}^{-1}$ et $8.8( \pm 1.8) \times 10^{-3} \mathrm{~s}^{-1}$, respectively. Hence, we deduce: $k \approx$ $18 \times 10^{2} \mathrm{M}^{-1} \mathrm{~s}^{-1}$. The fact that the consumption of linoleic acid hydroperoxides by metmyoglobin is strongly slowed down by BSA probably reflects LOOH-BSA binding. Similarly, the accommodation of linoleic acid molecules to the typical fatty acid binding sites of human serum albumin efficiently protects linoleic acid against the peroxidation induced by hydrophilic peroxyl radicals generated in the aqueous phase [25].

Importantly, metmyoglobin promotes the complete consumption of the hydroperoxides in large excess (4 equiv.) in less than $1 \mathrm{~min}$ in the absence of BSA and in $c a$. $10 \mathrm{~min}$ in the presence of BSA (0.74 equiv.). Simultaneously, at least 2 equivalents of ketones are produced. Hence, it is clear that a recycling of $\mathrm{MbFe}^{\mathrm{III}}$ takes place so that substoichiometric $\mathrm{MbFe}^{\mathrm{III}}$ concentrations are sufficient. The fact that ketones are the major products is consistent with a homolytic $\mathrm{LOOH}$ cleavage leading to $\mathrm{MbFe}^{\mathrm{IV}}=\mathrm{O}$ and lipid oxyl radicals $\left(\mathrm{LO}^{\circ}\right)$. Indeed, the major fate of the $\mathrm{LO}^{\bullet}$ radicals (besides possible epoxidation and/or cleavage into aldehydes and C-centered radicals) is ketone formation through a fast sequence of 1,2-shift of $\mathrm{H}$-atom with subsequent addition of $\mathrm{O}_{2}$ on the $\mathrm{C}$-centered radical thus formed and elimination of the hydroperoxyl radical (HOO ${ }^{\circ}$ ) (Scheme 3) [30]. Moreover, a process quickly regenerating $\mathrm{MbFe}^{\mathrm{III}}$ from $\mathrm{MbFe}^{\mathrm{IV}}=\mathrm{O}$ must operate. In the absence of BSA, LOOH themselves are the most likely reducing agents for this task in agreement with previous investigations [27,29]. In the reduction of $\mathrm{MbFe}^{\mathrm{IV}}=\mathrm{O}$ by $\mathrm{LOOH}, \mathrm{LOO}^{\bullet}$ radicals are produced (Scheme 3). A similar mechanism was proposed for the formation of epoxyalcohols in the reaction of metmyoglobin with $13-(9 Z, 11 E)-\mathrm{LOOH}$ at $\mathrm{pH} 7.4$ and $25^{\circ} \mathrm{C}$ [29]. It is consistent with the observation that one $\mathrm{O}_{2}$ molecule is consumed for the consumption of every two hydroperoxide molecules.

Monitoring the reaction between $\mathrm{MbFe}^{\mathrm{III}}$ and $\mathrm{LOOH}$ in the visible range shows a slow development of a weak absorption at $590 \mathrm{~nm}$ typical of ferrylmyoglobin (Fig. 6). In the presence of BSA, this process is of apparent first-order and largely independent of the hydroperoxide regioisomers selected and of the order of addition of the reagents $\left(\mathrm{MbFe}^{\mathrm{III}}\right.$ and 
LOOH). With $\mathrm{LOOH}$ in large excess (8 equiv.), the accumulation of $\mathrm{MbFe}^{\mathrm{IV}}=\mathrm{O}$ is followed by a slow decay (data not shown) whose apparent first-order rate constant $\left(14( \pm 7) \times 10^{-4} \mathrm{~s}^{-1}\right.$, $n=2$ ) is consistent with the auto-reduction rate constant already estimated. The plateau concentration of $\mathrm{MbFe}^{\mathrm{IV}}=\mathrm{O}$ (deduced from the molar absorption coefficient previously obtained) is in the range $5-30 \%$ of the initial $\mathrm{MbFe}^{\mathrm{III}}$ concentration depending on the initial LOOH concentration $\left(1-8\right.$ equiv.). This low concentration suggests that $\mathrm{MbFe}^{\mathrm{IV}}=\mathrm{O}$ is involved in reactions with $\mathrm{LOOH}$ [29] and possibly BSA [20] which prevent its substantial accumulation. It is also noteworthy that even at $\mathrm{pH} 7.4$ and $25^{\circ} \mathrm{C}$, i.e. in conditions where $\mathrm{MbFe}^{\mathrm{IV}}=\mathrm{O}$ is expected to be much more stable, its contribution to the total heme concentration is no higher than $40 \%$ after a 15 min incubation of $\mathrm{MbFe}^{\mathrm{III}}$ and $13-(9 Z, 11 E)$ LOOH (5 equiv.) [29].

The apparent first-order rate constant for ferryl accumulation depends on the initial LOOH concentration: $k_{\mathrm{obs}}=29( \pm 10) \times 10^{-4} \mathrm{~s}^{-1}(2.4$ equiv. LOOH, $n=4), 299( \pm 98) \times 10^{-4} \mathrm{~s}^{-1}$ ( 8 equiv. $\mathrm{LOOH}, n=7$ ). In the absence of $\mathrm{BSA}, k_{\mathrm{obs}}$ can also be estimated from the weak biexponential increase of $\mathrm{A}(590 \mathrm{~nm})$ observed after addition of 9-LOOH or 13-LOOH in low concentration (0.8 equiv.) to ensure complete solubility: $k_{\mathrm{obs}}=412( \pm 30) \times 10^{-4} \mathrm{~s}^{-1}(n=2)$. The order of magnitude of the bimolecular rate constant for the reaction between $\mathrm{MbFe}^{\mathrm{III}}$ and LOOH can be deduced from $k_{\mathrm{obs}}=k_{1} \mathrm{C}_{0}\left(\mathrm{C}_{0}\right.$ : initial LOOH concentration): $k_{1}=20-60$ and $900 \mathrm{M}^{-1} \mathrm{~s}^{-1}$ in the presence and absence of BSA, respectively. Although crude, those estimates are clearly much smaller than the values deduced from the conversion of $\mathrm{LOOH}$ into $\mathrm{L}=\mathrm{O}$ ( $2 \times 10^{3}$ and $25 \times 10^{3} \mathrm{M}^{-1} \mathrm{~s}^{-1}$ in the presence and absence of BSA, respectively). Similar discrepancies between the rate constants of $\mathrm{LOOH}$ consumption and ferryl formation were already pointed out in the investigation of the reaction between $\mathrm{MbFe}^{\mathrm{III}}$ and $13-(9 Z, 11 E)$ LOOH in neutral conditions [29]. They were interpreted by assuming that only a fraction of the $\mathrm{MbFe}^{\mathrm{III}}$ population is reactive owing to a conformational change in the protein chain caused by oxidative damage and making the heme pocket more accessible to the $\mathrm{LOOH}$ molecule. However, a preliminary oxidative damage required to prime $\mathrm{MbFe}^{\mathrm{III}}$ for reacting with $\mathrm{LOOH}$ should create lag phases in $\mathrm{LOOH}$ consumption and ferryl formation. They were not observed (Figs. 5 and 6).

A plausible mechanism for the metmyoglobin-induced decomposition of linoleic acid hydroperoxides has to account for the following observations: a catalytic $\mathrm{MbFe}^{\mathrm{III}}$ concentration is sufficient; low ferryl concentrations are slowly accumulated; LOOH consumption is a least one order of magnitude faster than ferryl accumulation; when two 
LOOH molecules are consumed, approximately one $\mathrm{L}=\mathrm{O}$ molecule is formed. The following mechanism can be proposed (Scheme 3): in a first step, $\mathrm{MbFe}^{\mathrm{III}}$ rapidly reacts with $\mathrm{LOOH}$ (rate constant $k_{\mathrm{a}}$ ) to form $\mathrm{L}=\mathrm{O}$, a one-electron oxidizing species (possibly, a hydroperoxyl radical) that is dissipated through the protein moiety and a new heme species equivalent to a one-electron oxidized metmyoglobin (molar absorption coefficient $\varepsilon_{\mathrm{a}}$ ). This species oxidizes a second $\mathrm{LOOH}$ molecule into the $\mathrm{LOO}^{\bullet}$ radical (leading to other lipid oxidation products) with regeneration of metmyoglobin (rate constant $k_{\mathrm{b}}$ ). In parallel, minor concentrations of $\mathrm{MbFe}^{\mathrm{IV}}=\mathrm{O}$ accumulates (rate constant $k_{1}$, molar absorption coefficient $\varepsilon_{1}$ ) via homolytic LOOH cleavage. Using this kinetic model, ferryl formation following the addition of $\mathrm{LOOH}$ (8 equiv.) to the metmyoglobin solution (Fig. 6B) can be successfully analyzed ( $\mathrm{r} \geq 0.999)$ by using the $\varepsilon_{1}$ value of $9450 \mathrm{M}^{-1} \mathrm{~cm}^{-1}$ determined previously (Table 1) and by identifying the second-order rate constant for LOOH consumption estimated by HPLC $\left(k=18 \times 10^{2} \mathrm{M}^{-1} \mathrm{~s}^{-1}\right)$ with $k_{\mathrm{a}}+k_{1}$. Thus, one obtains: $k_{\mathrm{b}}=373( \pm 151) \mathrm{M}^{-1} \mathrm{~s}^{-1}(n=6), \varepsilon_{\mathrm{a}}=2410( \pm 190) \mathrm{M}^{-1} \mathrm{~cm}^{-1}(n$ $=6$ ). As for the rate constant of ferryl formation, it was found slightly higher with 13-LOOH than with 9-LOOH: $k_{1}=146( \pm 11)(13-\mathrm{LOOH}, n=3)$ and $100( \pm 7)(9-\mathrm{LOOH}, n=3) \mathrm{M}^{-1}$ $\mathrm{cm}^{-1}$. From the values of the rate constants, the concentrations of the different species following the addition of linoleic acid hydroperoxides to a mildly acidic solution of metmyoglobin can be plotted as a function of time in the presence of serum albumin (Fig. 7). Alternative mechanisms involving $\mathrm{MbFe}^{\mathrm{IV}}=\mathrm{O}$ in the catalytic cycle or assuming a simple $\mathrm{MbFe}^{\mathrm{III}}$-catalyzed dehydration of $\mathrm{LOOH}$ into $\mathrm{L}=\mathrm{O}$ failed to account for the whole set of experimental observations. The main results of the kinetic analysis are summarized in Table 2.

Adding quercetin after $\mathrm{MbFe}^{\mathrm{IV}}=\mathrm{O}$ has reached its plateau concentration brings about a fast decrease of $\mathrm{A}(590 \mathrm{~nm})$, which can be analyzed by assuming a second-order reaction between $\mathrm{MbFe}^{\mathrm{IV}}=\mathrm{O}$ and quercetin (Fig. 6B). The corresponding rate constant $\left(k_{\mathrm{r}}=2660( \pm\right.$ 500) $\left.\mathrm{M}^{-1} \mathrm{~s}^{-1}, n=4\right)$ is higher than the one obtained when $\mathrm{H}_{2} \mathrm{O}_{2}$ is used for the formation of $\mathrm{MbFe}^{\mathrm{IV}}=\mathrm{O}$, as a possible consequence of the conformational changes in the BSA structure caused by the binding of $\mathrm{LOOH}$ and/or their products.

After addition of LOOH, the decay of the Soret band $\left(\lambda_{\max }=410 \mathrm{~nm}\right)$ of $\mathrm{MbFe}^{\mathrm{III}}$ (Fig. $8)$ is of apparent first-order in the presence of BSA $\left(k_{\mathrm{obs}}=12( \pm 2) \times 10^{-4} \mathrm{~s}^{-1}, n=2\right)$ and biexponential in its absence with a fast step characterized by $k_{\mathrm{obs}}=294( \pm 63) \times 10^{-4} \mathrm{~s}^{-1}(n=$ 2). Moreover, the decay of $\mathrm{A}(410 \mathrm{~nm})$ is much weaker than after addition of $\mathrm{H}_{2} \mathrm{O}_{2}$. In the latter case, the decay of $\mathrm{A}(410 \mathrm{~nm})$ is independent of BSA, of apparent first-order $\left(k_{\mathrm{obs}}=44.6\right.$ 
Version définitive du manuscrit publié dans / Final version of the manuscript published in : Free Radical Biology and Medicine, 2010, Article in press, DOI:10.1016/j.freeradbiomed.2010.01.037

Lorrain et al. Free Radical Biol. Med. 2010

$\left.( \pm 2.3) \times 10^{-4} \mathrm{~s}^{-1}, n=4\right)$ and paralleled with the increase in $\mathrm{A}(430 \mathrm{~nm})$, which is characteristic of $\mathrm{MbFe}^{\mathrm{IV}}=\mathrm{O}$ and is not observed with $\mathrm{LOOH}$. Thus, the weak decay of the Soret band of metmyoglobin after addition of the linoleic acid hydroperoxides suggests relatively minor changes at the heme and is consistent with the marginal formation of ferrylmyoglobin.

The rate constant for the reaction between $\mathrm{MbFe}^{\mathrm{III}}$ and $\mathrm{H}_{2} \mathrm{O}_{2}$ that can be estimated from $k_{\mathrm{obs}}\left(k_{1}=1500 \mathrm{M}^{-1} \mathrm{~s}^{-1}\right.$ ) is higher (a factor 2 ) than the one estimated by monitoring the formation of $\mathrm{MbFe}^{\mathrm{IV}}=\mathrm{O}$ at $590 \mathrm{~nm}$. This discrepancy could reflect the fact that the perferrylmyoglobin intermediate $\left(\mathrm{Mb}^{\bullet} \mathrm{Fe}^{\mathrm{IV}}=\mathrm{O}\right)$ is not exclusively converted into $\mathrm{MbFe}^{\mathrm{IV}}=\mathrm{O}$.

In summary, the kinetic analysis of the reaction between $\mathrm{MbFe}^{\mathrm{III}}$ and $\mathrm{LOOH}$ shows that the fast accumulation of linoleic acid-derived ketones cannot be ascribed to the sole homolytic cleavage of the linoleic acid hydroperoxides with subsequent formation of ferrylmyoglobin. In fact, the slow and marginal accumulation of $\mathrm{MbFe}^{\mathrm{IV}}=\mathrm{O}$ (evidenced by the kinetic analyses at 590 and $410 \mathrm{~nm}$ ), even in the presence of $\mathrm{LOOH}$ in large excess, suggests the occurrence of an alternative pathway independent of $\mathrm{MbFe}^{\mathrm{IV}}=\mathrm{O}$ and involving a much more reactive one-electron oxidized form of metmyoglobin (Scheme 3). This heme species is also the likely initiator of lipid peroxidation in mildly acidic solutions of linoleic acid $[9,10]$.

Although BSA strongly slows down LOOH consumption and the decay of the Soret band as a likely consequence of LOOH-BSA binding and possible ROS scavenging by BSA, the overall mechanism appears unchanged and also leads to ketone accumulation. Interestingly, the ferrylmyoglobin thus formed can be quickly reduced by BSA-bound quercetin, which confirms the possibility of long-range electron transfers taking place along the BSA structure from quercetin (bound to sub-domain IIA) to the iron-oxo center of ferrylmyoglobin, itself bound to BSA [25].

\section{Conclusion}

BSA can bind metmyoglobin and modulates its reactivity with hydroperoxides. Presumably because of their own binding to BSA, linoleic acid hydroperoxides are much more slowly converted into the corresponding ketones in the presence of BSA. In the presence or absence of BSA, the formation of ferrylmyoglobin is marginal in agreement with a dominant process involving a distinct one-electron oxidized form of metmyoglobin, which absorbs only weakly in the visible range. With hydrogen peroxide, a more contrasted situation emerges. On the one hand, the literature shows that BSA can reduce the hypervalent iron 
Version définitive du manuscrit publié dans / Final version of the manuscript published in : Free Radical Biology and Medicine, 2010, Article in press, DOI:10.1016/j.freeradbiomed.2010.01.037

Lorrain et al. Free Radical Biol. Med. 2010

species (perferrylmyoglobin, protonated ferrylmyoglobin) it forms by reacting with metmyoglobin as evidenced by the detection of long-lived BSA radicals. On the other hand, our work also shows that BSA does not affect the rate of ferrylmyoglobin formation while inhibiting the competitive formation of the redox-inactive green pigment in mildly acidic conditions. Finally, by binding quercetin BSA lowers but does not abolish its ability to reduce ferrylmyoglobin due to possible long-range electron transfers taking place within the ferrylmyoglobin - BSA - quercetin ternary complex.

\section{Acknowledgments}

Bénédicte Lorrain thanks the PACA Region and INRA for the financial support of a PhD grant. 
Version définitive du manuscrit publié dans / Final version of the manuscript published in : Free Radical Biology and Medicine, 2010, Article in press, DOI:10.1016/j.freeradbiomed.2010.01.037

Lorrain et al. Free Radical Biol. Med. 2010

\section{References}

[1] Bou, R.; Guardiola, F.; Codony, R.; Faustman, C.; Elias R. J.; Decker, E. A. Effect of heating oxymyoglobin and metmyoglobin on the oxidation of muscle microsomes. $J$. Agric. Food Chem. 56:9612-9620; 2008.

[2] Baron, C. P.; Andersen, H. J. Myoglobin-induced lipid oxidation: a review. J. Agric. Food Chem. 50:3887-3897; 2002.

[3] Gunther, M. R.; Kelman, D. J.; Corbett, J. T.; Mason, R. P. Self-peroxidation of metmyoglobin results in formation of an oxygen-reactive tryptophan-centered radical. J. Biol. Chem. 270:16075-16081; 1995.

[4] Kelman, D. J.; DeGray, J. A.; Mason, R. P. Reaction of myoglobin with hydrogen peroxide forms a peroxyl radical which oxidizes substrates. J. Biol. Chem. 269:7458$7463 ; 1994$.

[5] Lapidot, T.; Granit, R.; Kanner, J. Lipid peroxidation by "free" iron ions and myoglobin as affected by dietary antioxidants in simulated gastric fluids. J. Agric. Food Chem. 53:3293-3390; 2005.

[6] Baron, C. P.; Skibsted, L. H. Prooxidative activity of myoglobin species in linoleic acid emulsions. J. Agric. Food. Chem. 45:1704-1710; 1997.

[7] Cohn, J. S. Oxidized fat in the diet, postprandial lipaemia and cardiovascular disease. Curr. Opin. Lipidol. 13:19-24; 2002.

[8] Halliwell, B.; Rafter, J.; Jenner, A. Health promotion by flavonoids, tocopherols, tocotrienols, and other phenols: direct or indirect effects? Antioxidant or not? Am. J. Clin. Nutr. 81:268S-276S; 2005.

[9] Vulcain, E.; Goupy, P.; Caris-Veyrat, C.; Dangles, O. Inhibition of the metmyoglobininduced peroxidation of linoleic acid by dietary antioxidants: action in the aqueous vs. lipid phase. Free Radical Res. 39:547-563; 2005.

[10] Goupy, P.; Vulcain, E.; Caris-Veyrat, C.; Dangles, O. Dietary antioxidants as inhibitors of the heme-induced peroxidation of linoleic acid: mechanism of action and synergism. Free Radical Biol. Med. 43:933-946; 2007.

[11] Lorrain, B.; Dangles, O.; Genot, C.; Dufour, C. Chemical modeling of heme-induced lipid oxidation in gastric conditions and inhibition by dietary polyphenols. J. Agric. Food. Chem. 58:676-683; 2010. 
Version définitive du manuscrit publié dans / Final version of the manuscript published in : Free Radical Biology and Medicine, 2010, Article in press, DOI:10.1016/j.freeradbiomed.2010.01.037

Lorrain et al. Free Radical Biol. Med. 2010

[12] Galland, S.; Rakotomanomana, N.; Dufour, C.; Mora, N.; Dangles, O. Synthesis of hydroxycinnamic acid glucuronides and investigation of their affinity for human serum albumin. Org. Biomol. Chem. 6:4253-4260; 2008.

[13] Dufour, C.; Dangles, O. Flavonoid-serum albumin complexation: determination of binding constants and binding sites by fluorescence spectroscopy. Biochim. Biophys. Acta 1721:164-173; 2005.

[14] Dufour, C.; Loonis, M. Regio- and stereoselective oxidation of linoleic acid bound to serum albumin: identification by ESI-mass spectrometry and NMR of the oxidation products. Chem. Phys. Lipids 138:60-68; 2005.

[15] Tyssandier, V.; Reboul, E.; Dumas, J. F.; Bouteloup-Demange, C.; Armand, M.; Marcand, J.; Sallas, M.; Borel, P. Processing of vegetable-borne carotenoids in the human stomach and duodenum. Am. J. Physiol. 284:G913-G923; 2003.

[16] Ostdal, H.; Skibsted, L. H.; Andersen, H. J. Formation of long-lived protein radicals in the reaction between $\mathrm{H}_{2} \mathrm{O}_{2}$-activated metmyoglobin and other proteins. Free Radical Biol. Med. 23:754-761; 1997.

[17] Reeder, B. J.; Svistunenko, D. A.; Sharpe, M. A.; Wilson, M. T. Characteristics and mechanism of formation of peroxide-induced heme to protein cross-linking in myoglobin. Biochemistry 41:367-375; 2002.

[18] Catalano, C. A.; Choe, Y. S.; Ortiz de Montellano, P. R. Reactions of the protein radical in peroxide-treated myoglobin. Formation of a heme-protein cross-link. J. Biol. Chem. 264:10534-10541; 1989.

[19] Rao, S. I.; Wilks, A.; Hamberg, M.; Ortiz de Montellano, P. R. The lipoxygenase activity of myoglobin. Oxidation of linoleic acid by the ferryl oxygen rather than protein radical. J. Biol. Chem. 269:7210-7216; 1994.

[20] Kroger-Ohlsen, M. V.; Ostdal, H.; Andersen, M. L. The effect of pH on the oxidation of bovine serum albumin by hypervalent myoglobin species. Arch. Biochem. Biophys. 416:202-208; 2003.

[21] Hu, M.; Skibsted, L. H. Kinetics of reduction of ferrylmyoglobin by (-)epigallocatechin gallate and green tea extract. J. Agric. Food Chem. 50:2998-3003; 2002.

[22] Carlsen, C. U.; Kroger-Ohlsen, M. V.; Bellio, R.; Skibsted, L. H. Protein binding in deactivation of ferrylmyoglobin by chlorogenate and ascorbate. J. Agric. Food Chem., 48:204-212; 2000. 
Version définitive du manuscrit publié dans / Final version of the manuscript published in : Free Radical Biology and Medicine, 2010, Article in press, DOI:10.1016/j.freeradbiomed.2010.01.037

Lorrain et al. Free Radical Biol. Med. 2010

[23] Jorgensen, L. V.; Skibsted, L. H. Flavonoid deactivation of ferrylmyoglobin in relation to ease of oxidation as determined by cyclic voltametry. Free Radical Res. 28:335$351 ; 1998$.

[24] Irwin, J. A.; Ostdal, H.; Davies, M. J. Myoglobin-induced oxidative damage: evidence for radical transfer from oxidized myoglobin to other proteins and antioxidants. Arch. Biochem. Biophys. 362:94-104; 1999.

[25] Dufour, C.; Loonis, M.; Dangles, O. Inhibition of the peroxidation of linoleic acid by the flavonoid quercetin within their complex with human serum albumin. Free Radical Biol. Med. 43:238-250; 2007.

[26] Reeder, B. J.; Cutruzzola, F.; Bigotti, M. G.; Hider, R. C.; Wilson, M. T. Tyrosine as a redox-active center in electron transfer to ferryl heme in globins. Free Radical Biol. Med. 44:274-283; 2008.

[27] Reeder, B. J.; Wilson, M. T. The effects of $\mathrm{pH}$ on the mechanism of hydrogen peroxide and lipid hydroperoxide consumption by myoglobin: a role for the protonated ferryl species. Free Radical Biol. Med. 30:1311-1318; 2001.

[28] Allentoff, A. J.; Bolton, J. L.; Wilks, A.; Thompson, J. A.; Ortiz de Montellano, P. R. Heterolytic versus homolytic peroxide bond cleavage by sperm whale myoglobin and myoglobin mutants. J. Am. Chem. Soc. 114:9744-9749; 1992.

[29] Reeder, B. J.; Wilson, M. T. Mechanism of reaction of myoglobin with the lipid hydroperoxide hydroperoxyoctadecadienoic acid. Biochem. J. 330:1317-1323; 1998.

[30] Spiteller, G. Linoleic acid peroxidation - The dominant lipid peroxidation process in low density lipoprotein - and its relationship to chronic diseases. Chem. Phys. Lipids 95:105-162; 1998. 
Version définitive du manuscrit publié dans / Final version of the manuscript published in : Free Radical Biology and Medicine, 2010, Article in press, DOI:10.1016/j.freeradbiomed.2010.01.037

Lorrain et al. Free Radical Biol. Med. 2010

Table 1

Kinetic analysis of metmyoglobin reactions with hydrogen peroxide in the presence or absence of BSA (see Scheme 2 for kinetic model and text for details)

\begin{tabular}{ll}
\hline Rate constant & Mean value \\
\hline$k_{1}\left(\mathrm{MbFe}^{\mathrm{IV}}=\mathrm{O} \text { formation }\right)^{\mathrm{a}}$ & $640 \mathrm{M}^{-1} \mathrm{~s}^{-1}$ \\
$k_{2}\left(\mathrm{MbFe}^{\mathrm{IV}}=\mathrm{O} \text { auto-reduction }\right)^{\mathrm{a}}$ & $30 \times 10^{-4} \mathrm{~s}^{-1}$ (no BSA) \\
& $19 \times 10^{-4} \mathrm{~s}^{-1}(+\mathrm{BSA})$ \\
$k_{3}\left(\mathrm{GMbFe}^{\mathrm{III}}{\text { formation, no BSA })^{\mathrm{a}}}_{k_{\mathrm{r}}\left(\mathrm{MbFe}{ }^{\mathrm{IV}}=\mathrm{O}+\text { quercetin }^{\mathrm{b}}\right.}\right.$ & $270 \mathrm{M}^{-1} \mathrm{~s}^{-1}$ \\
& $73 \times 10^{2} \mathrm{M}^{-1} \mathrm{~s}^{-1}$ (no BSA) \\
& $680 \mathrm{M}^{-1} \mathrm{~s}^{-1}(+\mathrm{BSA})$ \\
\hline
\end{tabular}

${ }^{a}$ Curve-fitting of the spectral changes at $590 \mathrm{~nm}$ following the addition of $\mathrm{H}_{2} \mathrm{O}_{2}(60$ or 600 equiv.) to a $\mathrm{MbFe}^{\mathrm{III}}$ solution $(60 \mu \mathrm{M})$ in the presence or absence of BSA $(180 \mu \mathrm{M})$.

${ }^{\mathrm{b}}$ Curve-fitting of the spectral changes at $590 \mathrm{~nm}$ following the addition of quercetin $(15,30 \mathrm{or}$ $60 \mu \mathrm{M})$ to $\mathrm{MbFe}^{\mathrm{III}}(60 \mu \mathrm{M})$ previously activated by $\mathrm{H}_{2} \mathrm{O}_{2}(60 \mu \mathrm{M})$ in the presence of BSA $(180 \mu \mathrm{M})$. The $\mathrm{MbFe}^{\mathrm{IV}}=\mathrm{O}$ concentration at the time of quercetin addition was deduced from the kinetic analysis of the activation step (see text). 
Version définitive du manuscrit publié dans / Final version of the manuscript published in : Free Radical Biology and Medicine, 2010, Article in press, DOI:10.1016/j.freeradbiomed.2010.01.037

Lorrain et al. Free Radical Biol. Med. 2010

Table 2

Kinetic analysis of metmyoglobin reactions with linoleic acid hydroperoxides in the presence or absence of BSA (see text for details)

\begin{tabular}{|c|c|}
\hline Rate constant & Mean value \\
\hline \multirow[t]{2}{*}{ LOOH consumption $^{\text {a }}$} & $\geq 25 \times 10^{3} \mathrm{M}^{-1} \mathrm{~s}^{-1}$ (no BSA) \\
\hline & $18 \times 10^{2} \mathrm{M}^{-1} \mathrm{~s}^{-1}(+\mathrm{BSA})$ \\
\hline \multirow[t]{2}{*}{$\mathrm{MbFe}^{\mathrm{IV}}=\mathrm{O}$ formation $^{\mathrm{b}}$} & $900 \mathrm{M}^{-1} \mathrm{~s}^{-1}$ (no BSA) \\
\hline & $100-150 \mathrm{M}^{-1} \mathrm{~s}^{-1}(+\mathrm{BSA})$ \\
\hline$k_{\mathrm{r}}\left(\mathrm{MbFe} \mathrm{IV}^{\mathrm{IV}}=\mathrm{O}+\text { quercetin }\right)^{\mathrm{c}}$ & $2700 \mathrm{M}^{-1} \mathrm{~s}^{-1}(+\mathrm{BSA})$ \\
\hline
\end{tabular}

a Curve-fitting of the LOOH vs. time curves obtained by HPLC monitoring. Initial concentrations are $6.2 \mu \mathrm{M}$ for $\mathrm{MbFe}^{\mathrm{III}}, 25.5 \mu \mathrm{M}$ for $\mathrm{LOOH}$ and 0 or $18 \mu \mathrm{M}$ for BSA.

${ }^{\mathrm{b}}$ Curve-fitting of the spectral changes at $590 \mathrm{~nm}$ following the addition of LOOH (48 $\mu \mathrm{M}$ in the absence of BSA, 144 or $464 \mu \mathrm{M}$ in the presence of $180 \mu \mathrm{M}$ BSA) to a $\mathrm{MbFe}^{\mathrm{III}}$ solution $(60 \mu \mathrm{M})$. Experiments with addition of $\mathrm{MbFe}^{\mathrm{III}}$ to a solution of $\mathrm{LOOH}$ and BSA were also carried out in the same conditions.

${ }^{\mathrm{c}}$ Curve-fitting of the spectral changes at $590 \mathrm{~nm}$ following the addition of quercetin (30 or 60 $\mu \mathrm{M})$ to $\mathrm{MbFe}^{\mathrm{III}}(60 \mu \mathrm{M})$ previously activated by $\mathrm{LOOH}(464 \mu \mathrm{M})$ in the presence of BSA $(180 \mu \mathrm{M}) . \mathrm{MbFe}^{\mathrm{IV}}=\mathrm{O}$ concentration at the time of quercetin addition estimated from $\varepsilon\left(\mathrm{MbFe}^{\mathrm{IV}}=\mathrm{O}, 590 \mathrm{~nm}\right)=9500 \mathrm{M}^{-1} \mathrm{~cm}^{-1}$. 


\section{Legends}

Fig. 1. Visible spectra recorded during the reaction of $\mathrm{MbFe}^{\mathrm{III}}(60 \mu \mathrm{M})$ with $\mathrm{H}_{2} \mathrm{O}_{2}$ (1 equiv.) in the absence (A) or presence (B) of BSA (3 equiv.).

Fig. 2. Spectral changes following the addition of $\mathrm{H}_{2} \mathrm{O}_{2}$ (A: 1 equiv., B: 10 equiv.) to a $\mathrm{MbFe}^{\mathrm{III}}$ solution $(60 \mu \mathrm{M})$ in the absence (1) or presence (2) of BSA (3 equiv.). C: Spectral changes following the successive additions of $\mathrm{H}_{2} \mathrm{O}_{2}$ (1 equiv.) and quercetin (1 equiv.) to a $\mathrm{MbFe}^{\mathrm{III}}$ solution $(60 \mu \mathrm{M})$ in the absence (1) or presence (2) of BSA (3 equiv.).

Fig. 3. Time dependence of the different heme species during the reaction of metmyoglobin with $\mathrm{H}_{2} \mathrm{O}_{2}$ (1 equiv.) at $\mathrm{pH}$ 5.8. A: no $\mathrm{BSA}$, B: with $\mathrm{BSA}$ (3 equiv.). $\mathrm{MbFe}^{\mathrm{III}}(\mathbf{\square}), \mathrm{MbFe}^{\mathrm{IV}}=\mathrm{O}$ $(\bullet), \mathrm{oxMbFe}^{\mathrm{III}}(\boldsymbol{\Delta}), \mathrm{GMbFe}^{\mathrm{III}}(*)$. Rate constant values for the calculations are from Table 1.

Fig. 4. Quenching of the fluorescence of the quercetin-BSA complex (estimated concentration $\approx 25 \mu \mathrm{M}$ ) as a function of the metmyoglobin concentration (excitation at $450 \mathrm{~nm}, \mathrm{pH} 5.8$, $37^{\circ} \mathrm{C}$ ). The solid line is the result of the mathematical treatment assuming 1:1 binding between the two proteins: $K=23.9( \pm 0.2) \times 10^{3} \mathrm{M}^{-1}, f=204.0( \pm 0.2) \times 10^{4} \mathrm{M}^{-1}, \mathrm{r}=0.9999(\mathrm{pH}$ $\left.5.8,37^{\circ} \mathrm{C}\right)$. Insert: fluorescence emission spectra.

Fig. 5. HPLC monitoring of the conversion of linoleic acid hydroperoxides (1) into ketones (2) following the addition of $\mathrm{MbFe}^{\mathrm{III}}(6.2 \mu \mathrm{M})$ in the absence $(\boldsymbol{\Delta})$ or presence ( $\left.\boldsymbol{\square}\right)$ of BSA (18 $\mu \mathrm{M})$.

Fig. 6. Spectral changes following the addition of 13-LOOH (final concentration $=464 \mu \mathrm{M}$ ) to a $\mathrm{MbFe}^{\mathrm{III}}$ solution $(60 \mu \mathrm{M})$ in the presence of BSA $(180 \mu \mathrm{M})$. A: UV-visible spectra of $\operatorname{MbFe}^{\mathrm{III}}(\mathbf{1}, \mathrm{t}=0)$, after activation by $13-\mathrm{LOOH}(\mathbf{2}, \mathrm{t}=180 \mathrm{~s})$, after reduction by quercetin (final concentration $=60 \mu \mathrm{M})(3, \mathrm{t}=300 \mathrm{~s})$. B: kinetic monitoring at $590 \mathrm{~nm}$ (addition of LOOH at $\mathrm{t}=0$, addition of quercetin at $\mathrm{t} \approx 200 \mathrm{~s}$ ).

Fig. 7. Time dependence of the different species during the reaction of metmyoglobin with LOOH (ca. 8 equiv.) in the presence of BSA (3 equiv.). A: $\mathrm{MbFe}^{\mathrm{III}}(\mathbf{\bullet}), \mathrm{MbFe}^{\mathrm{III}}-1 \mathrm{e}^{-}(\bullet)$, 
Version définitive du manuscrit publié dans / Final version of the manuscript published in : Free Radical Biology and Medicine, 2010, Article in press, DOI:10.1016/j.freeradbiomed.2010.01.037

Lorrain et al. Free Radical Biol. Med. 2010

$\mathrm{MbFe}^{\mathrm{IV}}=\mathrm{O}(\mathbf{\Delta}), \mathbf{B}: \mathrm{LOOH}(\boldsymbol{\bullet}), \mathrm{L}=\mathrm{O}(\bullet)$. The rate constant values used in the calculations are: $k_{\mathrm{a}}=1680 \mathrm{M}^{-1} \mathrm{~s}^{-1}, k_{\mathrm{b}}=370 \mathrm{M}^{-1} \mathrm{~s}^{-1}, k_{1}=120 \mathrm{M}^{-1} \mathrm{~s}^{-1}$.

Fig. 8. Modifications of the Soret band following the addition of LOOH (final concentration = $9.6 \mu \mathrm{M}, \mathbf{A}$ ) or $\mathrm{H}_{2} \mathrm{O}_{2}$ (final concentration $=3 \mu \mathrm{M}, \mathbf{B}$ ) to a $\mathrm{MbFe}^{\mathrm{III}}$ solution $(3 \mu \mathrm{M})$ in the presence of BSA $(9 \mu \mathrm{M})$. C: kinetic monitoring at $410 \mathrm{~nm}$. 1: $\mathrm{H}_{2} \mathrm{O}_{2}+\mathrm{BSA}, \mathbf{2}$ : LOOH, 3: $\mathrm{LOOH}+\mathrm{BSA}$.

Scheme 1. Activation of metmyoglobin by hydrogen peroxide and subsequent deactivation by electron donors (PP: porphyrin nucleus, Gb: globin, oxGb: oxidized globin).

Scheme 2. Activation of metmyoglobin by hydrogen peroxide and subsequent deactivation by quercetin. A simplified scheme for kinetic analysis (PP: porphyrin nucleus, Gb: globin, oxGb: oxidized globin).

Scheme 3. Metmyoglobin-catalyzed decomposition of linoleic acid hydroperoxides: a radical mechanism involving a one-electron oxidized metmyoglobin intermediate. 


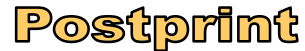

Version définitive du manuscrit publié dans / Final version of the manuscript published in : Free Radical Biology and Medicine, 2010, Article in press, DOI:10.1016/j.freeradbiomed.2010.01.037

Lorrain et al. Free Radical Biol. Med. 2010
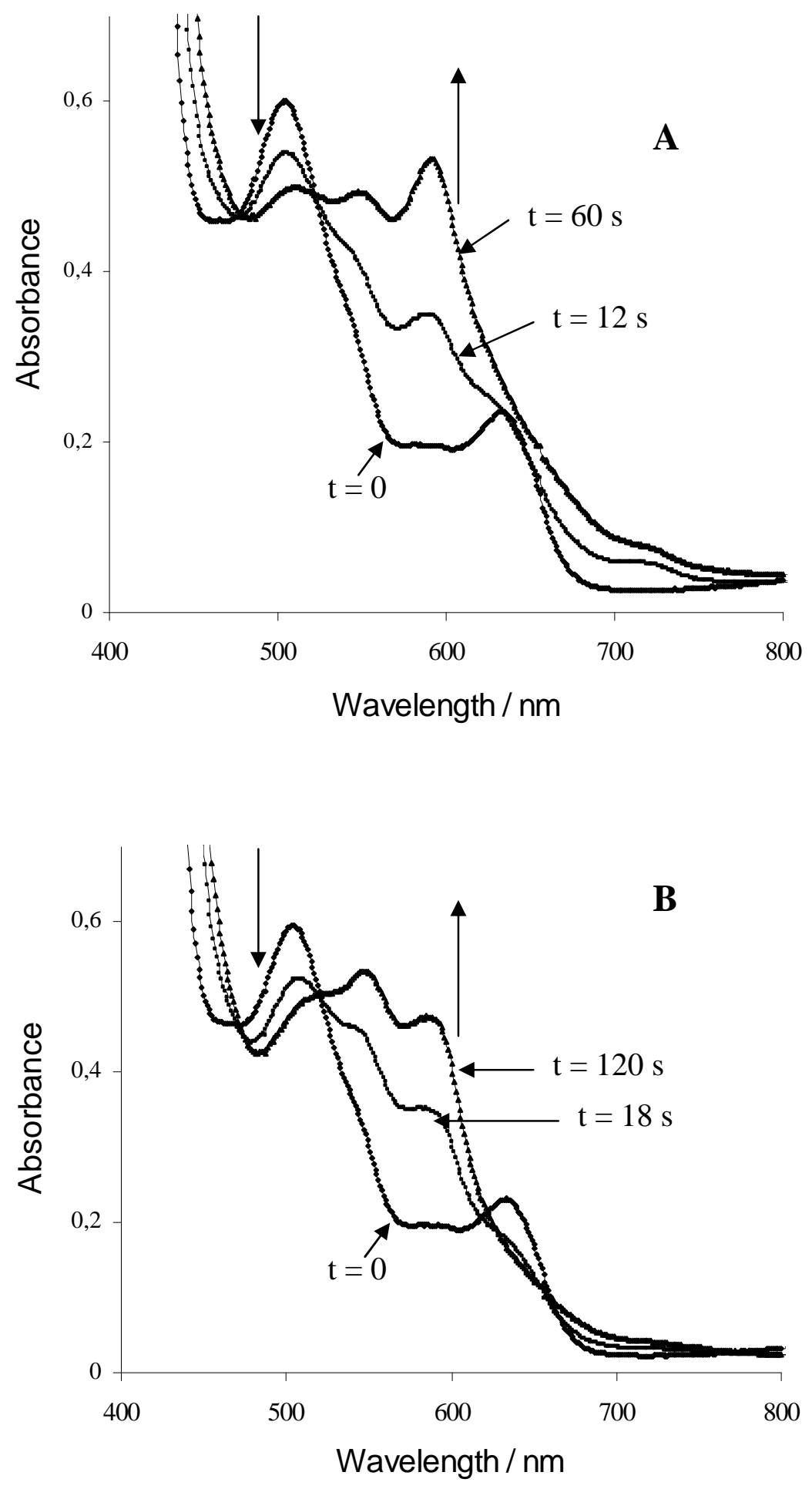

Fig. 1 


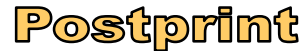

Version définitive du manuscrit publié dans / Final version of the manuscript published in : Free Radical Biology and Medicine, 2010, Article in press, DOI:10.1016/j.freeradbiomed.2010.01.037

Lorrain et al. Free Radical Biol. Med. 2010
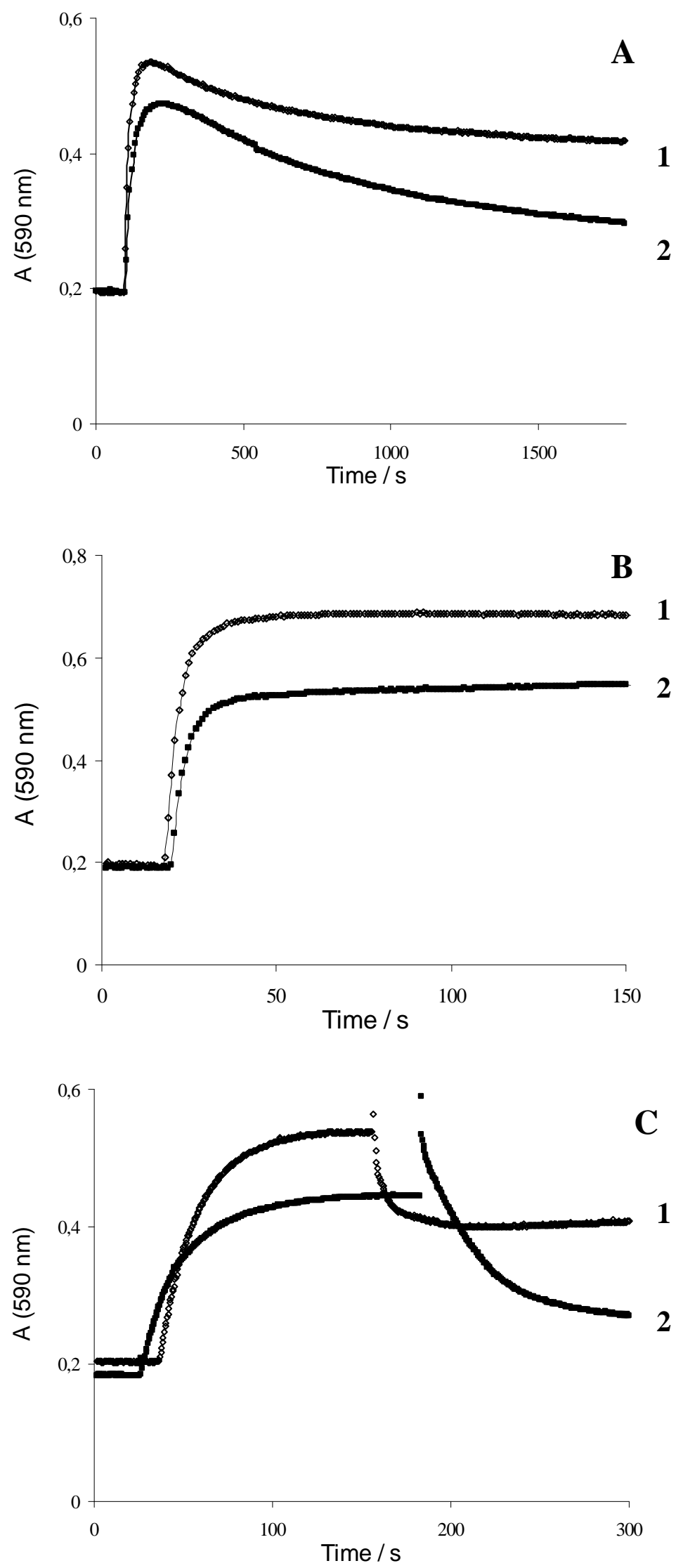

Fig. 2 


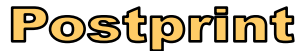

Version définitive du manuscrit publié dans / Final version of the manuscript published in : Free Radical Biology and Medicine, 2010, Article in press, DOI:10.1016/j.freeradbiomed.2010.01.037

Lorrain et al. Free Radical Biol. Med. 2010
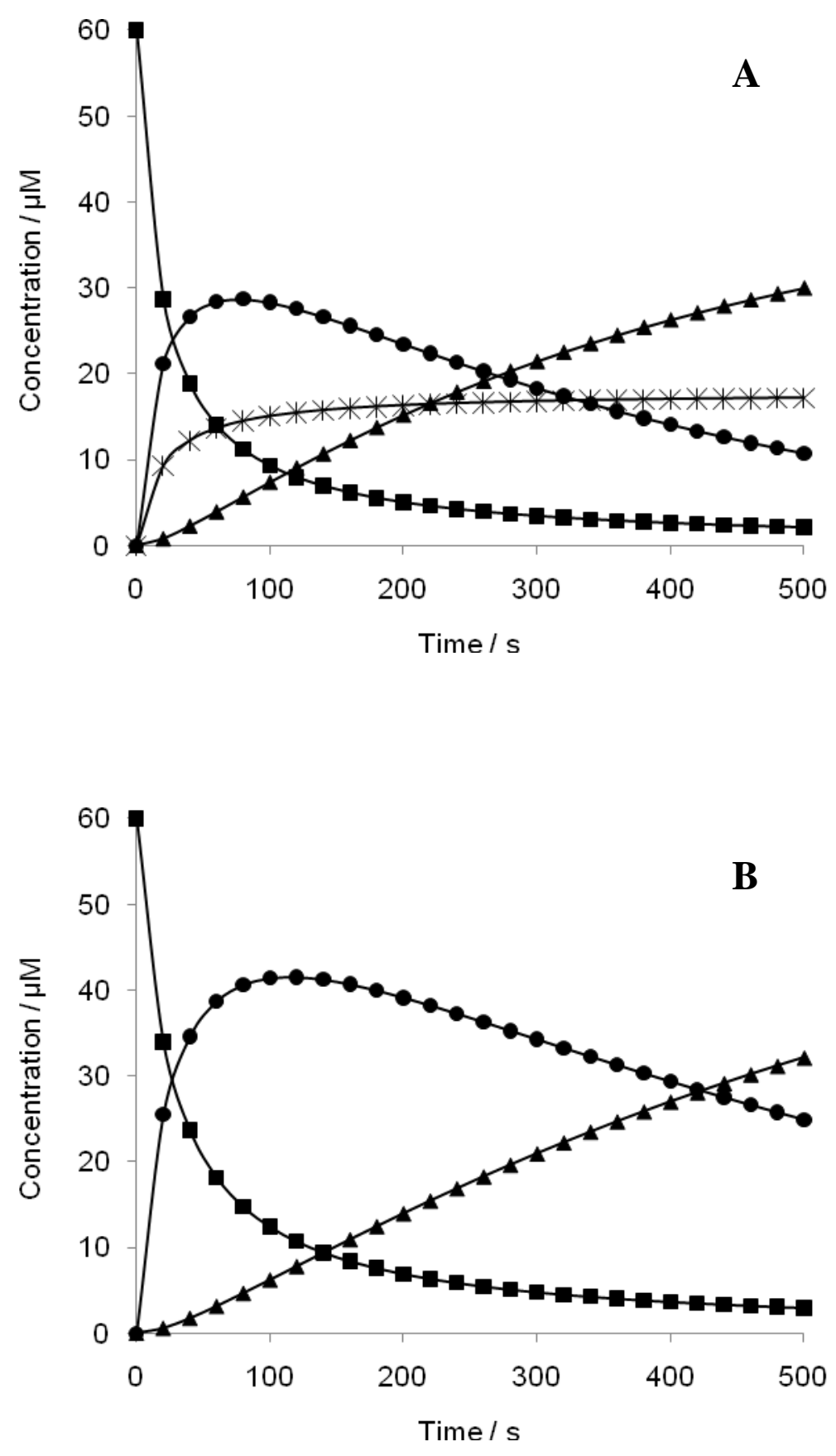

Fig. 3 
Version définitive du manuscrit publié dans / Final version of the manuscript published in : Free Radical Biology and Medicine, 2010, Article in press, DOI:10.1016/j.freeradbiomed.2010.01.037

Lorrain et al. Free Radical Biol. Med. 2010

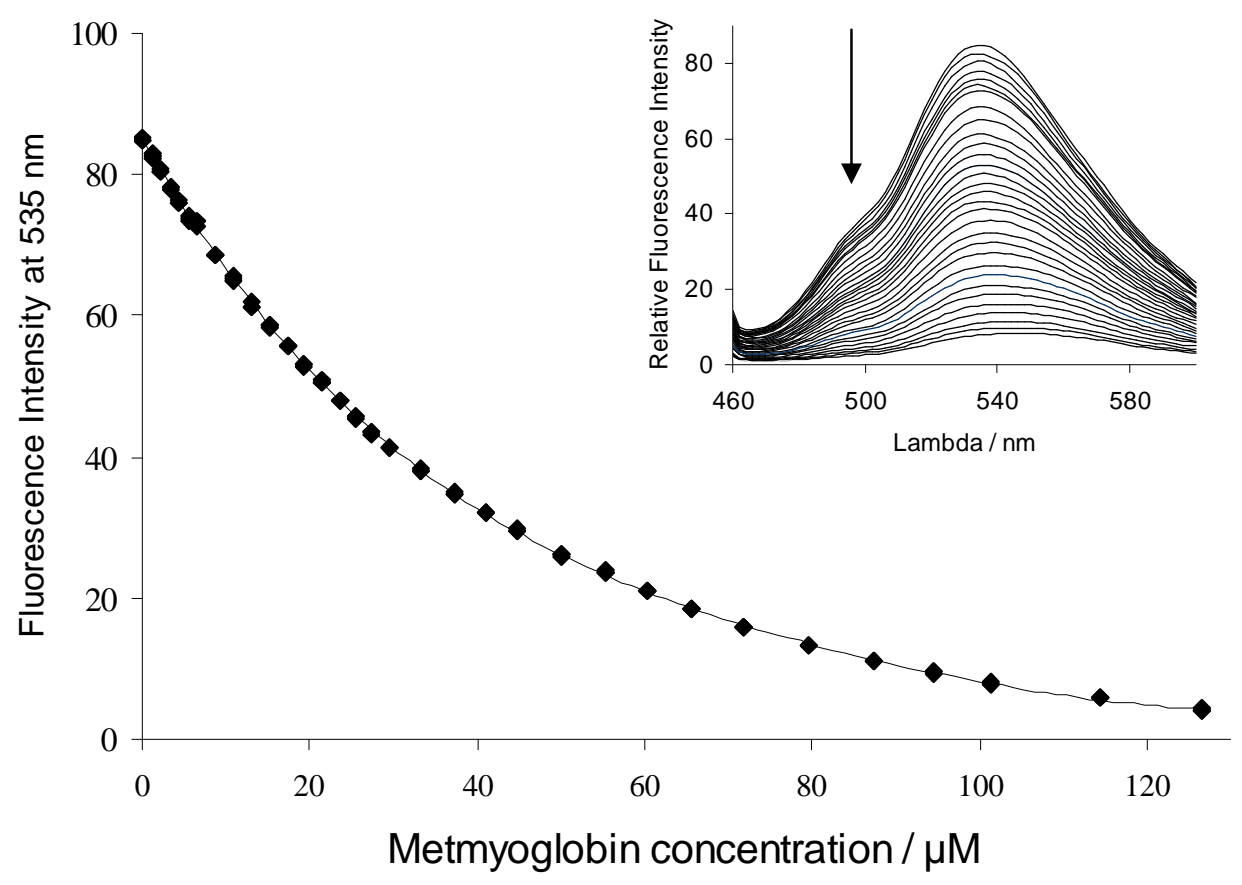

Fig. 4 
Version définitive du manuscrit publié dans / Final version of the manuscript published in : Free Radical Biology and Medicine, 2010, Article in press, DOI:10.1016/j.freeradbiomed.2010.01.037

Lorrain et al. Free Radical Biol. Med. 2010

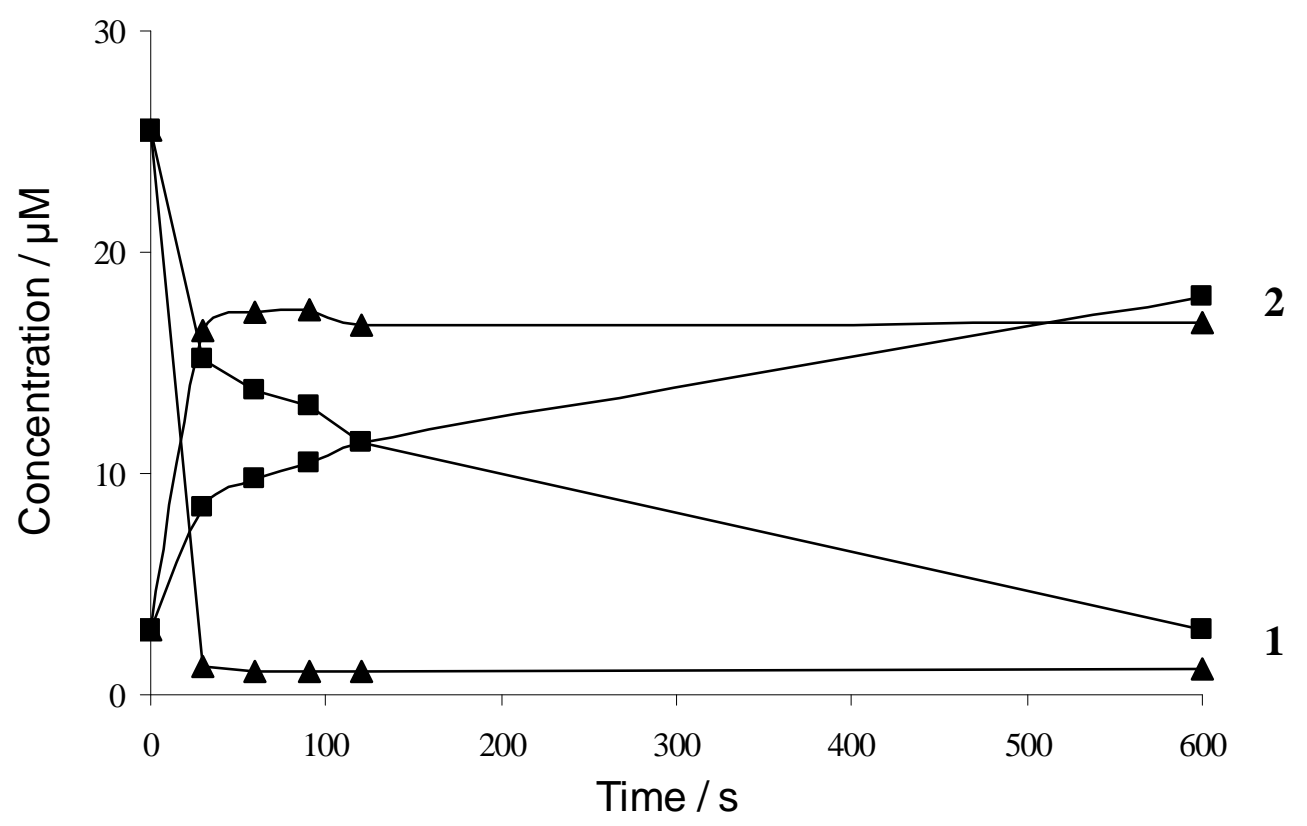

Fig. 5 


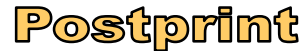

Version définitive du manuscrit publié dans / Final version of the manuscript published in : Free Radical Biology and Medicine, 2010, Article in press, DOI:10.1016/j.freeradbiomed.2010.01.037

Lorrain et al. Free Radical Biol. Med. 2010
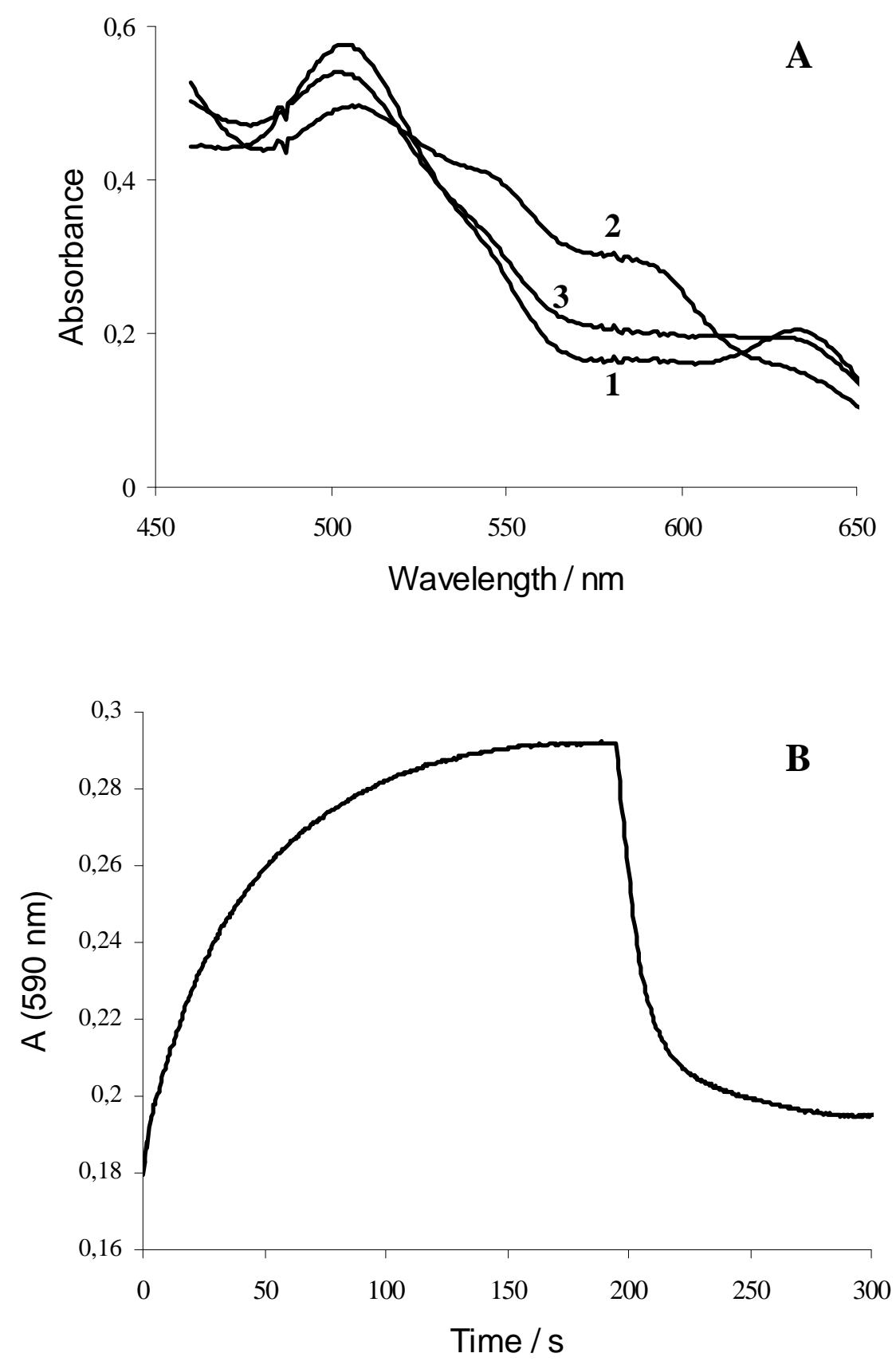

Fig. 6 
Version définitive du manuscrit publié dans / Final version of the manuscript published in : Free Radical Biology and Medicine,

2010, Article in press, DOI:10.1016/j.freeradbiomed.2010.01.037

Lorrain et al. Free Radical Biol. Med. 2010
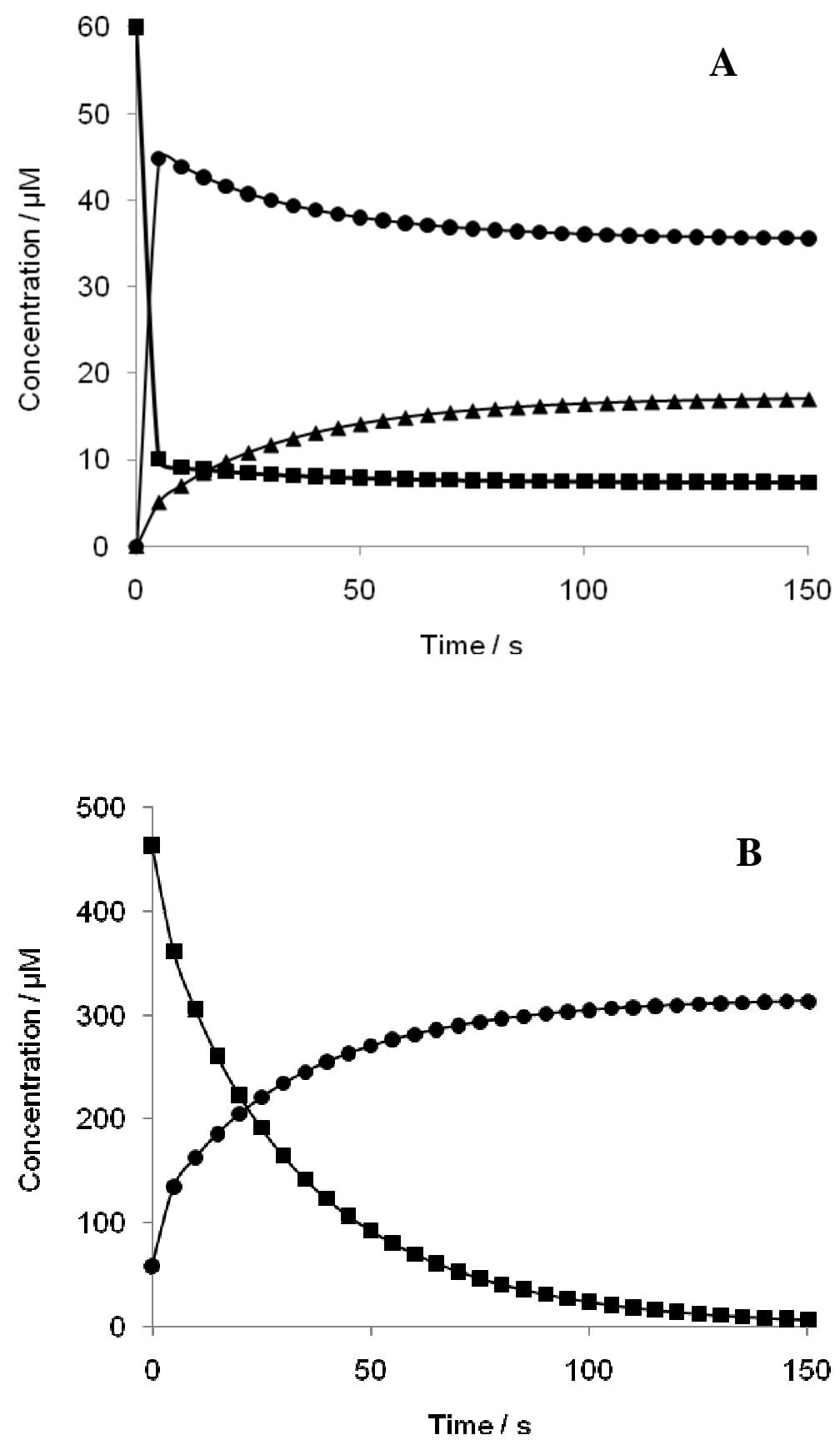

Fig. 7 
Version définitive du manuscrit publié dans / Final version of the manuscript published in : Free Radical Biology and Medicine, 2010, Article in press, DOI:10.1016/j.freeradbiomed.2010.01.037

Lorrain et al. Free Radical Biol. Med. 2010
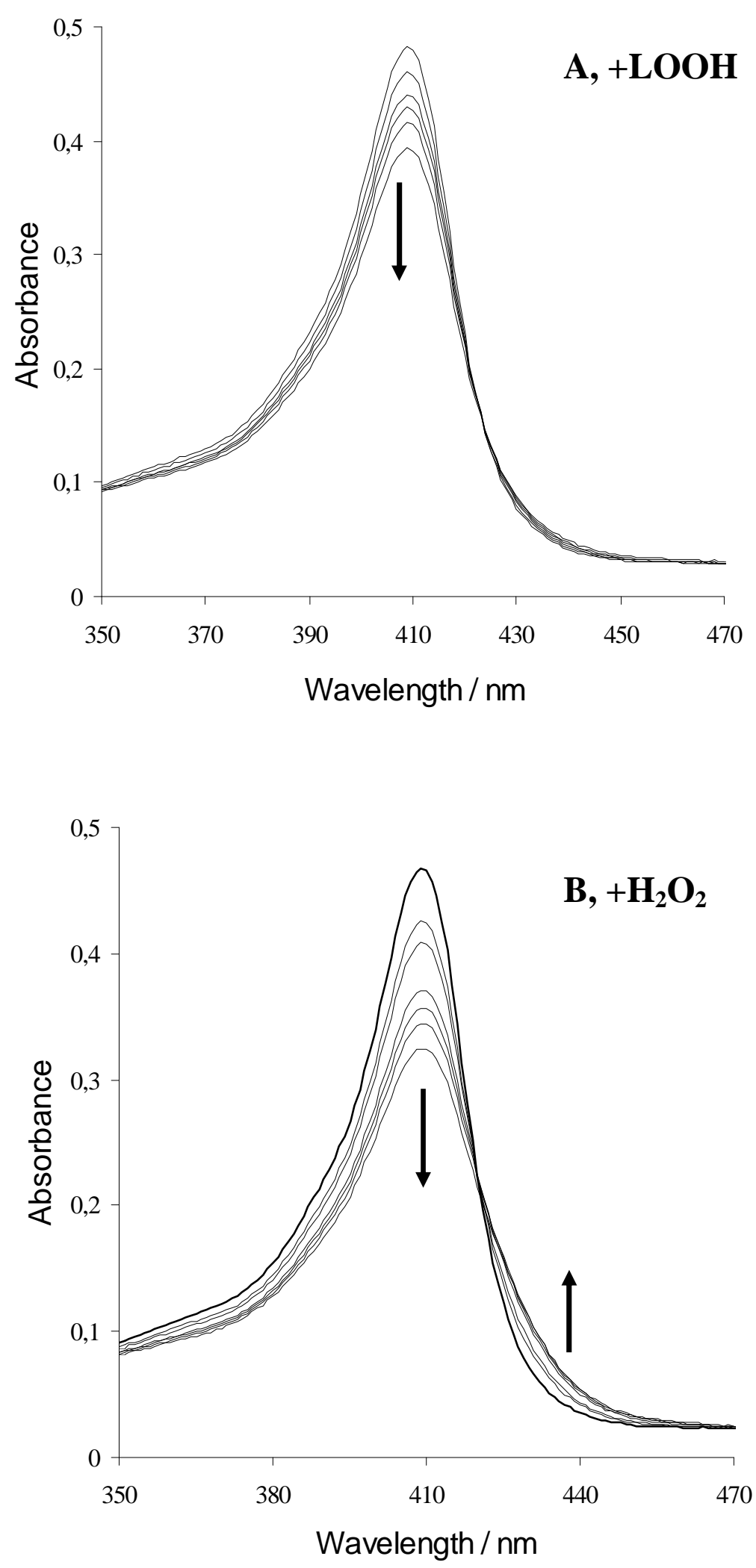
Version définitive du manuscrit publié dans / Final version of the manuscript published in : Free Radical Biology and Medicine, 2010, Article in press, DOI:10.1016/j.freeradbiomed.2010.01.037

Lorrain et al. Free Radical Biol. Med. 2010

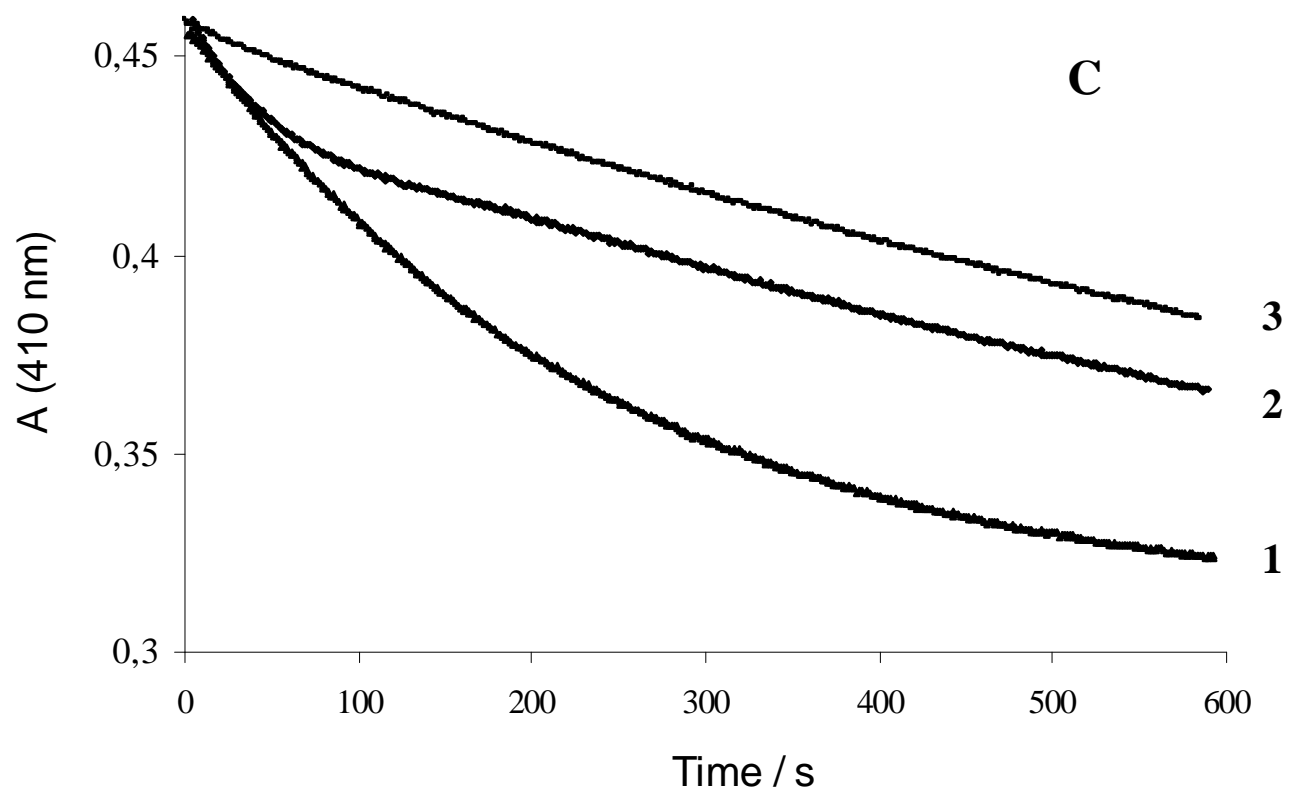

Fig. 8 


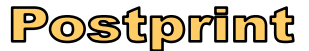

Version définitive du manuscrit publié dans / Final version of the manuscript published in : Free Radical Biology and Medicine, 2010, Article in press, DOI:10.1016/j.freeradbiomed.2010.01.037

Lorrain et al. Free Radical Biol. Med. 2010
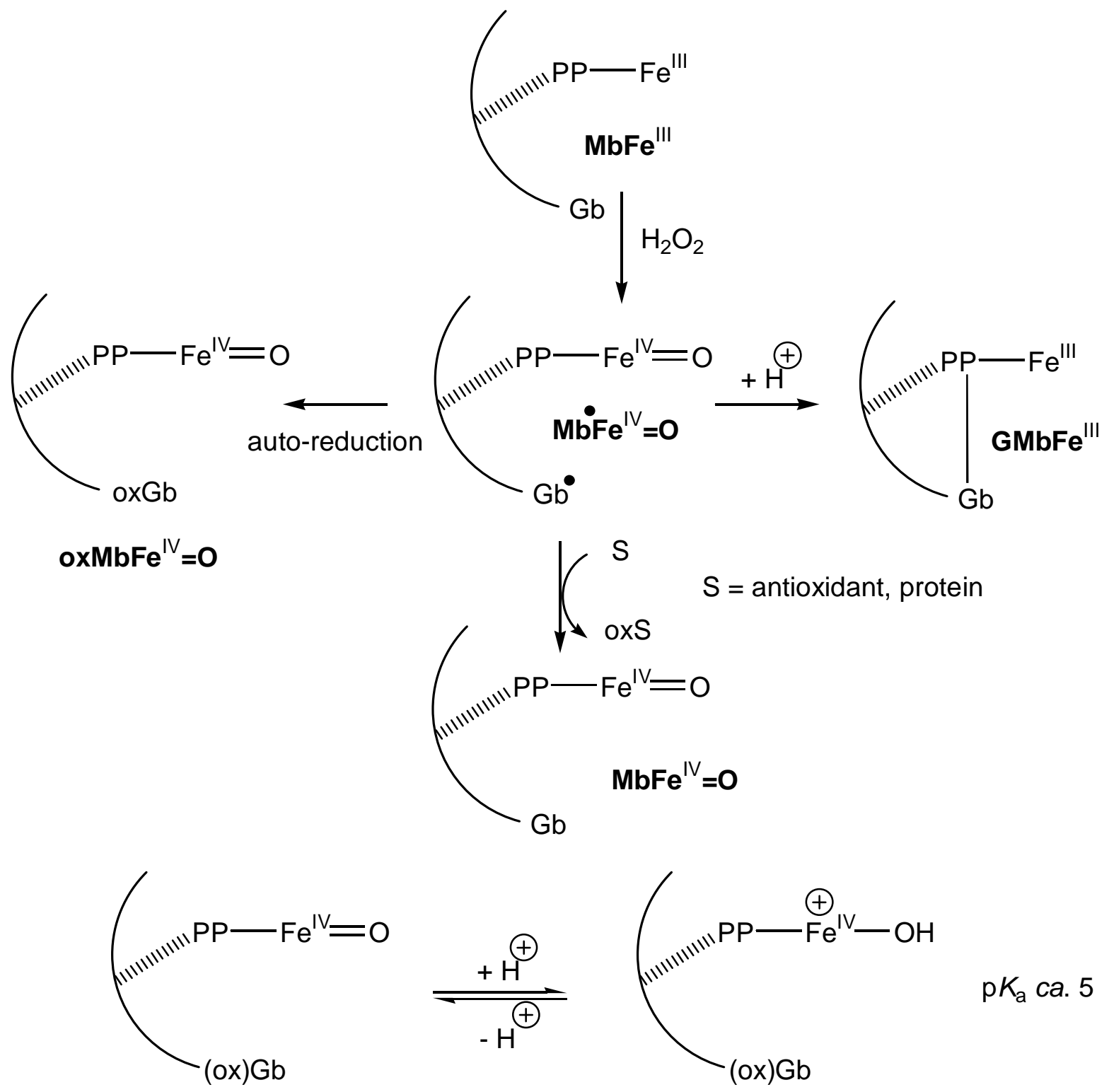

$\mathrm{p} K_{\mathrm{a}}$ ca. 5

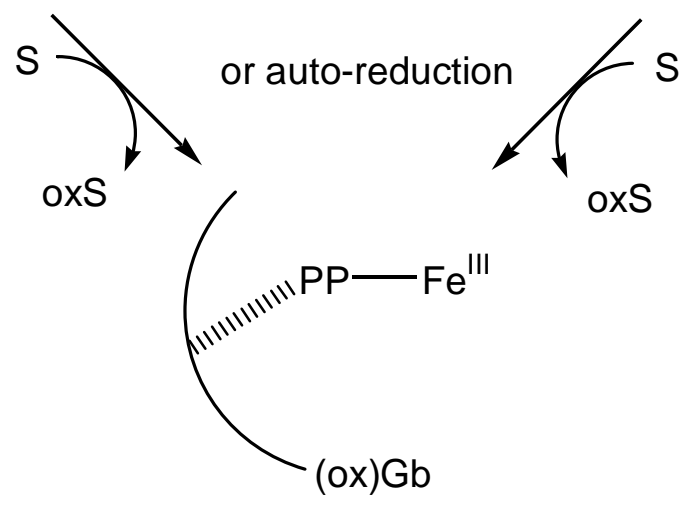

\section{Scheme 1}




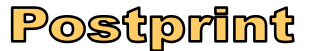

Version définitive du manuscrit publié dans / Final version of the manuscript published in : Free Radical Biology and Medicine, 2010, Article in press, DOI:10.1016/j.freeradbiomed.2010.01.037

Lorrain et al. Free Radical Biol. Med. 2010
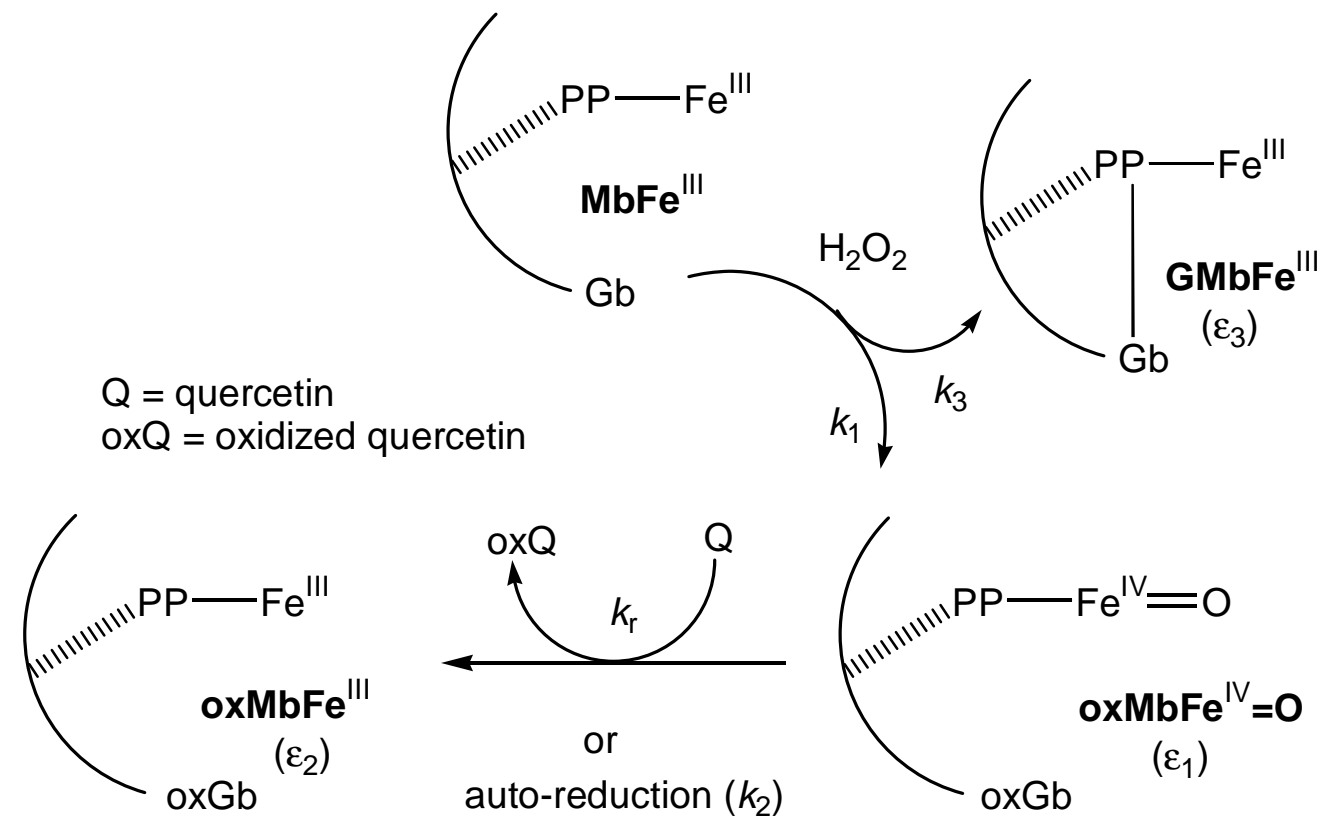<smiles>O=C(OCc1ccc(O)c(O)c1)OC(=O)c1oc2cc(O)cc(O)c2c(=O)c1O</smiles>

Scheme 2 


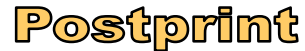

Version définitive du manuscrit publié dans / Final version of the manuscript published in : Free Radical Biology and Medicine, 2010, Article in press, DOI:10.1016/j.freeradbiomed.2010.01.037

Lorrain et al. Free Radical Biol. Med. 2010
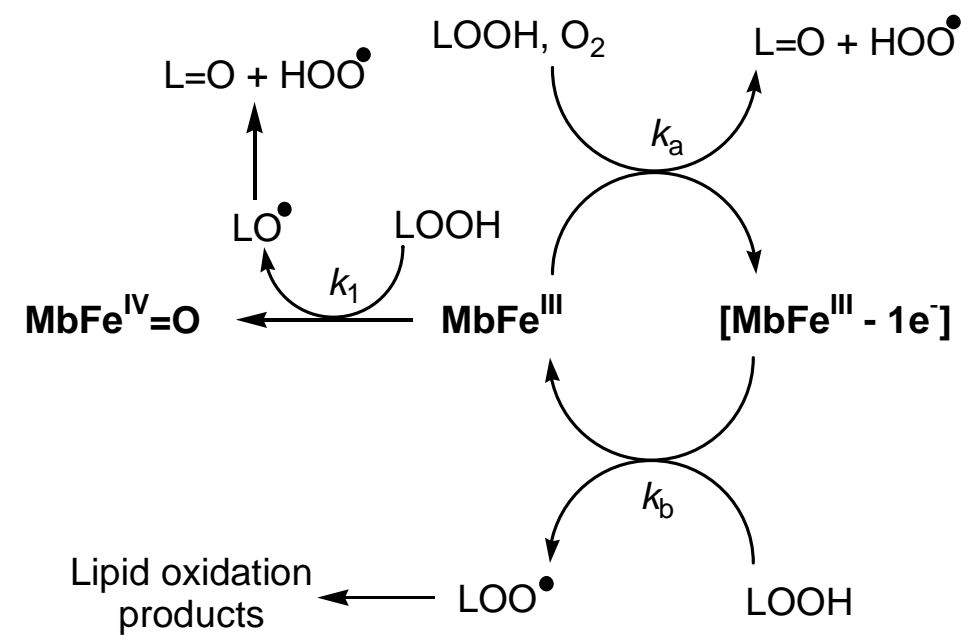

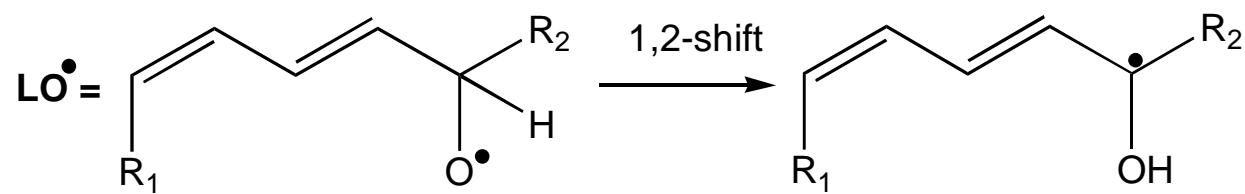

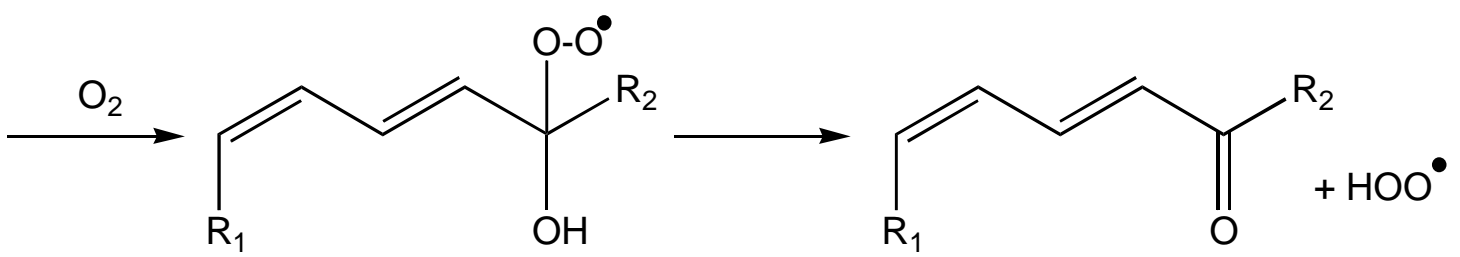

Scheme 3 